\title{
Pragmatic or Heretic? Editing Catechisms in Mexico in the Age of Discoveries and Reformation (1539-1547)
}

José Luis Egío

\author{
Introduction: Paleochristian passéisme, Pragmatic Simplicity and \\ Concerns for Orthodoxy in the First American Catechisms
}

The path toward the definition and implementation of specific points of orthodoxy in the catechetical literature developed for the Early Modern Americas has been studied at length by a number of scholars (Saranyana, ${ }^{1}$ Borges, ${ }^{2}$ Estenssoro Fuchs, ${ }^{3}$ Roulet, ${ }^{4}$ Duve, ${ }^{5}$ etc.). While the first catechisms and manuals of piety that were used to instruct native Americans in the Christian religion were the result of the individual initiatives of bishops and friars, by the middle of the sixteenth century, responding to the growing concerns about the potential spread of Protestant ideas in the New World and about probable indigenous misunderstandings as to orthodoxy, major steps were taken in order to develop precise and orthodox instruments of indoctrination. The specificities of the missionary context in the Americas, apparently requiring the standardisation of evangelisation tools (catechisms, ${ }^{6}$ manuals

1 Saranyana (ed.), Teología en América Latina, vol. 1, chapters I-VI, 35-255; Saranyana, "Métodos de catequización”.

2 Borges, "Métodos de persuasion" and Borges, "La nueva cristiandad indiana", 573-613.

3 Estenssoro, Del paganismo a la santidad.

4 Roulet, L'évangelisation des Indiens du Mexique, chapters III \& IV, 59-107.

5 Duve, "Catequesis y derecho canónico entre el Viejo y el Nuevo Mundo", 131-145.

6 The historiography on catechetical materials does not always apply homogeneous criteria while classifying the different subgenres of this important field in religious literature. Confusion is prevalent, especially when dealing with doctrinas and catecismos. While Gil tries to distinguish carefully between doctrinas and catecismos, Resines considers "ambos términos como equivalentes, pues el uso ha determinado un empleo indistinto". Gil, Primeras "doctrinas" del Nuevo Mundo, 275-278; Resines, Catecismos Americanos del siglo XVI, vol. 1, 22. In general terms, catechisms have a dialogical structure, that is to say, the exposition is ordered by a series of questions and answers which helps the catechumen to learn the contents by heart. By contrast, with doctrines, the ideas are communicated unilaterally. Nevertheless, 
for confessors, prayer books, etc.), converged in the 155 os with a general trend in the Spanish Empire toward the definition of a religious orthodoxy constructed against Protestant and some Erasmian conceptions which had gained great influence in the Spanish universities, Church, cultural circles ${ }^{7}$ and even among some of the closest advisers of Charles v (Mercurino Gattinara, Alfonso de Valdés, etc.). ${ }^{8}$

A parallel impulse toward the standardisation of this kind of religious literature came from Rome as well, where, as is well known, shortly after the conclusion of the Council of Trent and following its resolutions, an official catechism was written and approved (1566). ${ }^{9}$ For the first time, the popular instruction of Christianity was meticulously and authoritatively established and fixed. This measure had a major impact in the Spanish American dioceses. In fact,

this formal denomination does not appear to be clear even for the writers of these different subgenres in the Late-Mediaeval and Early Modern periods, such that no distinction will be made between catecismos and doctrinas in this present contribution. A conditioning element could be the fact that it is relatively common for a particular book to include contents presented in the form of a doctrina as well as in the style of a catecismo and, beyond that, even including parts laid out as per other pastoral subgenres (confesionarios, tratados de oración, artes del buen morir, etc.). This kind of assembly of heterogeneous materials - which, in fact, made up a kind of manual for priests and missionaries - used to be published under a vague, general title (Doctrina Cristiana, Regla Cristiana, Libro de la Doctrina Cristiana, Suma de Doctrina Cristiana, Catecismo, etc.). The very complex Regla cristiana breve edited by Juan de Zumárraga - the first Archbishop of Mexico - in 1547 is an illustrative example of this cumulative logic, Zumárraga, Regla christiana breve. For the American context, subgenres such as the indigenous vocabularies and artes de la lengua are also common components of this kind of catechetical literature. See Zwartjes (ed.), Las gramáticas misioneras de tradición hispánica (siglos XVI-XVII).

7 By the 1520s, not only the humanist University of Alcalá and distinguished teachers at the University of Salamanca such us Nebrija and the Vergara brothers, but also the most prominent Churchmen in Spain, the archbishop of Toledo Alonso de Fonseca and the General Inquisitor, Alonso Manrique, were open sympathisers of Erasmus. After Manrique's fall in disgrace, the Spanish followers of Erasmus began to be prosecuted, accused of being closet supporters of Luther. The increasing repression and confusion of Erasmian and Protestant ideas led to the prohibition of Erasmus' writings in the Spanish Index of 1559 (following the criteria adopted by the Roman Inquisition that same year). For a classic perspective on the Erasmian decades (1520s-1550s) in Spain, see Kamen, The Spanish Inquisition, chapter 3.

8 The experts on the topic are divided between those who consider Erasmus and Valdés as relevant guiding figures in Carlos v's entourage and those who, reducing the importance of religious and ideological principles, give more important to the strategic, military and economic probable motivations for Carlos' enterprises such as the famous Sacco di Roma (1527). A contemporary re-appraisal of this debate. Tubau, "Alfonso de Valdés y la política imperial del canciller Gattinara", 17-43.

9 Catechismus Ex Decreto SS. Concilii Tridentini ad Parochos. 
catechetical materials inspired in the Roman catechism of 1566 were approved by most provincial councils and local synods. ${ }^{10}$

The converging dynamic, to which the scholars mentioned above referred in a long diachronic perspective, can also be seen from a synchronic point of view. In fact, if one avoids a teleological perspective regarding the whole process of catechetical uniformisation - taking the Council of Trent, the Spanish and Roman prohibition on Erasmus' writings (1559) and the strengthening of the Spanish Inquisition in the second half of sixteenth century as key explanatory events and predetermined goals - another kind of intriguing convergence can be detected.

On the one hand, the motivations of the different missionary agents, which seem to converge in the significant period between the 153 os and 1540 os (the period in which the first serious steps to teach the Gospel to the native Americans were taken), ${ }^{11}$ involved the need for brevity and paedagogical simplification, features belonging to catechisms and, in general terms, to all pragmatic religious literature. Even so, the encounter with the rustic populations of the Americas led the promoters of their Christianisation to go one step further in the traditional quest for the simplicity that characterises catechetical literature. ${ }^{12}$ Given the many uncertainties as to the intellectual capacity of the natives ${ }^{13}$ and their own ability to teach the complex mysteries of the Christian

10 A general perspective in Duve, "Catequesis y derecho canónico entre el Viejo y el Nuevo Mundo", 136-140.

11 After the first three decades of Spanish presence in the New World, characterised by an almost purely rhetorical use of Christianity as a set of ideological arguments justifying the war on, plundering and enslavement of the Amerindian populations. According to testimonies of this period such as the chronicles of Gonzalo Fernández de Oviedo, the conversions to Christianism in this period cannot be properly considered as true conversions, given that they were obtained either by force or after a superficial and multitudinous administration of baptism. "É assi parésçeme á mí que para esta creencia desta gente nuevamente allegada á la iglesia, que es más menester de baptiçarlos é dexarlos, pues que sin creer, como lo diçe la mesma verdad evangélica, no se pueden salvar, sino condenar", Fernández de Oviedo, Historia general y natural, Section Three, lib. XLII, cap. III, 6o.

12 It is important to mention that this kind of catechetical literature was also in vogue in Europe and the Iberian Peninsula just in the period in which the early evangelisation of America took place. See Duve, "Catequesis y derecho canónico entre el Viejo y el Nuevo Mundo", 135 .

13 Uncertainties that, until this period, remained even among those who are usually regarded as the most outspoken defenders of the indigenous populations. The case of Vitoria, who, in his Relectio De Indis prior (1539), did not manage to give a definite opinion about the supposed mental incapacity of the Indians, is paradigmatic. An English translation in Vitoria, On the American Indians, eds. Lawrance and Pagden, Q. 3, Art. 8, $\S 18,290-291$. 
faith in a multitude of unknown, still unwritten, languages, ${ }^{14}$ the missionaries were forced to reflect carefully on what the vital essence of the Christian faith at its most basic was. Any possible solution to this catechetical dilemma had to take into account not only the most salvific dogmas and practices but also to envisage, from a pragmatic point of view, which of these eternal truths could be easily communicated.

Looking beyond the American context, just in the decades in which the transcendental choices regarding the Christianisation of the native Americans were to be made, the debate as to what was essential and what were but "human inventions"15 corrupting Christianity was at its height. In this period, Protestants and Erasmians shared a strong desire to return to a primitive Church, an ideal Church that both of them conceived as essentially simple and pure, standing as such in complete opposition to the corrupt and deformed Church of the era.

As this chapter shows, the ideals of pragmatic simplicity and reformed purification - counterbalanced by the need to maintain a certain distance from the intentionally schismatic approach of the Protestants - came together to establish an uneasy, fragile, short-lived but extremely interesting alliance until the second half of the sixteenth century. Focusing on the Peruvian context, Estenssoro has referred - in other terms - to this problematic alliance as one of the main challenges neglected by previous scholars and which has still to be covered in the historiography regarding catechetical literature. ${ }^{16}$ In their books about the missionary strategies and administration of the sacraments in early colonial Mexico, classic scholars such as Robert Ricard ${ }^{17}$ and contemporary ones such as Osvaldo Pardo, ${ }^{18}$ have also called attention to the way in which these converging but somehow contradictory motivations, polarised the Mendicants when they attempted to define the minimal knowledge that penitents or candidates for baptism had to prove before obtaining absolution or being permitted to receive the first sacrament of the Church. Nevertheless, the

\footnotetext{
14 See Durston, Pastoral Quechua. The History of Christian Translation in Colonial Peru, 1550-1650; Valdeón, Translation and the Spanish Empire in the Americas, 111-113.

15 The famous Institutio Christianae Religionis of Jean Calvin was published in Latin in 1536 and in French in 1541. Even more than in Luther, the writings of the Genevan reformer show a radical opposition between the true and the false Church, the pure words of God Himself and human idolatrous inventions. Calvin's virulent opinion on this issue can be found in Calvin, Institution de la religion Chrestienne, chapter XIII, "Des traditions humaines".

16 Estenssoro, Del paganismo a la santidad, 32.

17 Ricard, La conquista espiritual de México.

18 Pardo, The Origins of Mexican Catholicism, 6-8.
} 
general approach of Ricard and Pardo, trying to synthesize many controversial arguments on baptism, confirmation, penance, confession and the Eucharist having taken place throughout the long sixteenth century, led them to review only in passing the concrete collocation of the above-mentioned ideals in the Mexican catechetical literature.

Considering the absence of an intellectual in-depth analysis of the first Mexican doctrines comparable ${ }^{19}$ to the works that Estenssoro dedicated to their Peruvian equivalents, this chapter will cover how the ideals of pragmatic simplicity, restoration of the early Church and defence of orthodoxy against the schismatic converge in the short doctrines edited by bishop Juan de Zumárraga in the period of $1539-1547$.

\section{The Triumphant and Pure Primitive Church. Translation of an Ideal into Mexico by Juan de Zumárraga}

Among the catechetical materials developed in America in the first half of 16th century, Zumárraga's doctrines figure among the better examples of this convergence of epochal motivations. First bishop of the diocesis of Mexico and former Franciscan friar, Juan de Zumárraga, is a well-known and well-studied figure. ${ }^{20}$ He arrived in Mexico in December of $1528,{ }^{21}$ was consecrated bishop in 1533 (even if he was acting de facto as a bishop before his official consecration) and, shortly before his death (1548), was appointed archbishop after the elevation of the Mexican diocese to the category of archdiocese. Zumárraga was responsible for a missionary policy in which the destructive dimension (the bishop took an active role in the demolition and transformation of

19 With regard to the early Mexican doctrines, reliance has, in this contribution, been placed on the important, but, nevertheless, very descriptive studies of scholars such as Gil, Primeras "doctrinas" del Nuevo Mundo; Resines, Catecismos Americanos del siglo XVI, vol. 1; Saranyana (ed.), Teología en América Latina, vol. 1; Alejos-Grau, Juan de Zumárraga y su "Regla Cristiana breve"; Medina, Doctrina cristiana para instrucción de los Indios; Guillermo Durán, Monumenta catechetica hispanoamericana (siglos XVI-XVIII), 3 vols.; Mira Mira, Estudio histórico-genético de la "Doctrina breve" (1543-44) de Juan de Zumárraga; Adeva Martín, "Fray Juan de Zumárraga: Regla Cristiana Breve".

20 See García Icazbalceta, Don Fray Juan de Zumárraga. Primer obispo y arzobispo de México, 4 vols.; Greenleaf, Zumárraga and the Mexican Inquisition, 1536-1543; Greenleaf and Kaveny, Zumárraga and his family: letters to Vizcaya 1536-1548.

21 García Icazbalceta, Don Fray Juan de Zumárraga. Primer obispo y arzobispo de México, vol. 1, 34; AGI, México, 1088, L.1, fols. 31v-33v. 
temples, burning of codices and annihilation of items related to pre-Hispanic religions $)^{22}$ was as important as the creative one.

A very widespread attitude toward Zumárraga's religious commitment is to consider it as a "celo exagerado por mantener la pureza de una religión que apenas se estaba introduciendo en estas partes del mundo". From this perspective, such zeal is regarded as deeply Spanish and closely linked to a caricatured fanaticism "de la España de aquella época" fuelled by the victory over the Muslims of Granada. ${ }^{23}$ It is arguable that this historiographical perspective ignores the great complexity of the Spanish and European religious landscape in the first half of the sixteenth century and does not take into account that Zumárraga's zeal had little to do with an Andalusian context far away from his experience and motivations. It should, rather, be related to the general trend toward a purer and more authentic Christianity to which many men of this time adhered.

Being a tireless denouncer of the thefts and abuses that unscrupulous friars, churchmen and laymen carried out in his diocese, Zumárraga, longing, after a very idealised fashion, for the discipline prevalent in the early Church, came into contact with Francisco de Vitoria, the famous theology professor at the University of Salamanca, asking him - through Charles $\mathrm{V}$ - to make a personal selection from among his more virtuous pupils of twelve apostles for the New World ${ }^{24}$ and praised the strong discipline that only the Carthusians - faithful custodians of the "santas antigüedades de la Iglesia" - among his contemporaries seemed to respect. ${ }^{25}$ It is interesting that, in his disciplinary denunciations,

22 Ricard, La conquista espiritual de México, 96-108; Greenleaf, Zumárraga and the Mexican Inquisition, 1536-1543.

23 Romero Galván, "Review of Sonia Corcuera de Mancera, De pícaros y malqueridos", 15-17.

24 "Real Cédula al maestro Fray Francisco de Vitoria, catedrático de Prima en la Universidad de Salamanca, dándole cuenta de que el obispo de México ha escrito que en aquella tierra hay necesidad de clérigos para instruir y convertir a los indios, y que ha sabido que él tiene buenos discípulos, entre los que debe escoger doce, a los que se les proveerá en Sevilla de pasaje y matalotaje para ir a aquellas tierras", 18 April 1539, AGI, Indiferente, 423, L.19, fols. 234V-235r. Edited by Beltrán de Heredia, Los manuscritos del Maestro Fray Francisco de Vitoria O.P., 163 .

25 “Oh bendita religión, donde los ojos que desean no ver del todo desterradas las santas antigüedades de la Iglesia y hallar algún rastro de ellas, las pueden hallar y ver conservadas como en su primera institución!". “Edicto del obispo Zumárraga exhortando a los vecinos de México a que asistan a la Iglesia". In: García Icazbalceta, Don Fray Juan de Zumárraga. Primer obispo y arzobispo de México, vol. 4, n. 28, 266, 269-270. Zumárraga's admiration for the Cartusian discipline and for members of this order such as Denis van Ryckel led him to order the printing of a Compendio breve que tracta dela manera de como se han de hazer las processiones: compuesto por Dionisio Rickel cartuxano in 1544. 
Zumárraga often blames the instituted Roman Church for its chicanery and the growing contradictory legislation conceding privileges and dispensations regarding even the most elementary "tradiciones santas" of the Ancient Church. ${ }^{26}$

Zumárraga's passéisme had not only a disciplinary dimension but was also at the core of his missionary commitment, which drew on the affinity that, from his perspective, existed between the theological condition of the Amerindians and the pagans of apostolic times. To a similar challenge, a similar response: according to Zumárraga, the better catechetical materials were to be found in the historical heritage of the Church, conveniently cleansed of any kind of innovations and excrescences. Zumárraga edited this religious patrimony in several doctrinas printed in Mexico between 1539 and 1547, only some of which have survived. ${ }^{27}$ The doctrines in which Zumárraga

The contemporary Spanish American historiography tends to underscore the influence exerted by late mediaeval mystics such as Denis the Carthusian on Zumárraga's thinking in the context of the reforms launched by Cisneros to impose a strict observance among the Franciscan friars. Josep Ignasi Saranyana, "El impulso editorial de Juan de Zumárraga y sus denuncias proféticas", in Saranyana (ed.), Teología en América Latina, vol. 1, 49-55; "Evaluación del 'erasmismo' de Zumárraga”, in Gil, Primeras "doctrinas” del Nuevo Mundo, 374-384; Alejos-Grau, Juan de Zumárraga y su "Regla Cristiana breve", 62; Guillermo Durán, Monumenta catechetica hispanoamericana (siglos XVI-XVIII), vol. 2, 97. The writings on this matter of Saranyana, Durán, Gil and Alejos Grau seem to be motivated by an explicit will to counter the most widespread French and Anglo-Saxon perspective of an Erasmian Zumárraga, which, in the Spanish American context, was strongly supported in several publications of Almoina, "El erasmismo de Zumárraga"; Almoina, "Introducción". This polemic, a kind of post-mortem trial of Zumárraga's orthodoxy, seems quite sterile. Both influences - late mediaeval mysticism and Erasmian new / old motifs seem to have exercised equal influence on Zumárraga.

26 For example, in the exhortation he addressed to the vecinos of Mexico asking them to attend the Church more often, he complains pointedly of the legislation related to private chapels: "[...] en esta nuestra infelicísima edad, en que la soberbia humana y regalo corporal ha ensanchado mucho sus leyes y costumbres con gran derogación de las tradiciones santas que los santísimos padres antiguos hicieron en las cortes que el Espíritu Santo celebró en los concilios de la Iglesia Católica", García Icazbalceta, Don Fray Juan de Zumárraga. Primer obispo y arzobispo de México, vol. 4, n. 28, 270.

27 No copies of a Doctrina cristiana breve para enseñanza de los niños and a Doctrina cristiana por preguntas y respuestas have been preserved, see Wilkinson (ed.), Iberian Books, 770. The same would have happened with two other doctrines: First, a Breve y más compendiosa doctrina christiana en lengua mexicana y castellana (1539), mentioned by Fernando Gil in his rewriting of the bibliographical repertoires of Icazbalceta and Medina; see Gil, Primeras "doctrinas" del Nuevo Mundo, 284-313. Second, a Doctrina christiana: en que en suma se contiene todo lo principal y necessario que el Cristiano debe sabery obrar (1545-1546), considered by Resines as the first edition of the later Doctrina 
played a greater role are the following: Doctrina cristiana para instrucion $y$ información de los indios: por manera de historia (1544), ${ }^{28}$ Doctrina breve muy provechosa (1543-44), ${ }^{29}$ Doctrina christiana mas cierta y verdadera para gente sin erudicion y letras (1546) $)^{30}$ and Regla christiana breve (1547). ${ }^{31}$ Other important catechetical books, such as the influential Doctrina christiana breve traduzida en lengua Mexicana $(1546)^{32}$ by Alonso de Molina, re-edited on several occasions, were not the work of Zumárraga himself but came to be printed thanks to the explicit support of the bishop. We find echoes of Zumárraga's commitment with his pastoral and formative duties even after his death (1548) and in regions far away from Mexico. For example, as late as 1552, the Dominican Diego Ximénez published in Lisbon an Enchiridiono Manual de Doctrina Christiana initially conceived as a doctrine for the Mexican "sheep". According to the foreword of its author, he had begun to write this doctrine in 1541 on request from Zumárraga, assisted by "other friends and bishops from New Spain." 33

cristiana más cierta y verdadera para gente sin erudicion y letras; seeResines, Catecismos Americanos del siglo XVI, vol. 2, 409-420. From a Manual de adultos printed in $1540-$ the very first book published in the New World - only three pages have survived, BNE, $\mathrm{R} / 29333$. The website of the Project Primeros libros de las Américas (www.primeroslibros. org) also includes some pages of a very synthetic Cartilla para la enseñanza de la doctrina cristiana en lengua zotzil, latina y castellana, [México?], [Juan Pablos?], [1547?], which may have been published during Zumárraga's episcopacy. The developers of this ambitious digital library have helped to discard some erroneous data and interpretations found in Gil. For example, it is now clear that the Doctrina Cristiana in lengua Mexicana written by Pedro de Gante (1553) was not published during the lifetime of Zumárraga, but rather slightly thereafter.

28 Córdoba, Zumárraga and Betanzos, Doctrina cristiana para instruciony información de los indios: por manera de historia.

29 Zumárraga, Doctrina breve muy provechosa.

30 Zumárraga, Doctrina cristiana: mas cierta y verdadera para gente sin erudicion y letra.

31 Zumárraga, Regla christiana breve.

32 The first pages of these books use to mention that they were printed "por mandado" of Zumárraga. It is the case for Alonso de Molina's doctrine and for the second edition of Pedro de Córdoba's doctrine (1548), a bilingual Castilian-Náhuatl edition of the text that Zumárraga had amended and edited in 1544. Córdoba, Zumárraga and Betanzos, Declaracion y exposicion de la doctrina christiana en lengua española y Mexicana. Molina, Doctrina christiana breve traduzida en lengua Mexicana.

33 It would be a Herculean task to undertake a thorough and exhaustive search of every one of the doctrines resulting from the firm commitment of Zumárraga. I am very grateful to Manuela Bragagnolo for this curious and telling reference. Ximénez, Enchiridion o Manual de doctrina christiana, "Prologo del autor", fol. †iiir. 

llana" (1544)

Even if the Doctrina cristiana para instrucion y informacion de los indios: por manera de historia (1544) is not usually studied as a substantial part of Zumárraga's catechetical effort, ${ }^{34}$ but rather as the printed version of Pedro de Córdoba's and other early Dominican missionaries' perspective, ${ }^{35}$ it is clear that, in the twenty-three years following Córdoba's death (1521), many interventions on the part of later Dominican friars - especially, from the province of Santiago de México, Domingo de Betanzos - and of the zealous bishop Juan de Zumárraga contributed to modifications to Cordoba's catechetical legacy. This hypothesis is corroborated by the source itself. In fact, a deeper look into this early doctrina - beyond the front pages from which the authors of bibliographical repertoires used to source the information for their accounts - permits the discovery of explicit mentions of the important role played by Betanzos and Zumárraga. In the colophon, it is stated that both of them added "algunas cosas" to the materials used by the Dominican friars to indoctrinate the natives in the Caribbean. ${ }^{36}$ Zumárraga's shadow glides over this colophon: he requests "por caridad" of the members of the Orders that they should work on the instruction and conversion of the natives and on the translation into the "lenguas de indios" of this same doctrine. Zumárraga also clarifies the role that the book should play among the different catechetical initiatives that he had launched. While this brief doctrine was very appropriate for preaching to "incipient" catechumens, "the other one", together with the Tripartito of John Gerson, would satisfy the special needs of "proficient" neophytes. What doctrina this "other one" could, be is still a matter of discussion among scholars. It is arguable that Zumárraga could only be referring to the Doctrina breve muy provechosa. Despite its misleading title, it was much longer than the Doctrina cristiana para instrucion y informacion de los indios,

34 For instance, Gil dedicates to this book only three descriptive pages of his monograph on Zumárraga's writings, Gil, Primeras "doctrinas" del Nuevo Mundo, 294-296.

35 See Guillermo Durán, Monumenta catechetica hispanoamericana (siglos XVI-XVIII), vol. 1, 198-201 and the introductory study to another contemporary edition by Medina, Doctrina cristiana para instrucción de los Indios.

36 The colophon of the Doctrina cristiana para instrucion y informacion de los indios states: “[...] aquí se acaba la presente doctrina que los padres de la orden de sancto Domingo en principio nombrados ordenaron para el catecismo e instrucion de los indios [...]. Y va mas declarada y en algunas cosas añadida por los muy reverendos padres el Obispo de mexico y fray Domingo de betanços". 
which was printed this same year, ${ }^{37}$ as was the Tripartito del cristianísimo $y$ consolatorio doctor Juan Gerson de doctrina cristiana, ${ }^{38}$ to which Zumárraga also refers to in the colophon.

Zumárraga does not appeal to the conclusions of a certain Junta ${ }^{39}$ while justifying the imposition of this sole doctrine. With the warning and rebuking tone to which he would resort in later doctrinas - evoking Erasmus to justify his position - he insists on some of the objective pragmatic criteria that were behind his choice:

El qual [Zumárraga, who had covered the publication expenses] pide y ruega mucho a los padres religiosos que entienden en la instrucion y conversión delos indios: ante todas cosas procuren de les predicar y hazer entender esta doctrina breve y llana: pues conocen su

37 For the purposes of this contribution, Durán's hypothesis is followed. He considers the Doctrina breve of 1543-1544 as the doctrine for proficient catechumens, arguing that "es una exposición igualmente sencilla, escrita en estilo llano para común inteligencia, pero su contenido es más denso y sistemático", Guillermo Durán, Monumenta catechetica hispanoamericana (siglos XVI-XVIII), vol. 1, 208. The scholars who put aside the reworking of Córdoba's doctrine from the ensemble of Zumárraga's catechetical initiatives are usually led to confusion by the title of the books. "La Doctrina breve (1544), serviría para el primer nivel o principiantes; la Doctrina Cristiana y su suplemento (1546), para el segundo nivel, que sería el de los que ya se habían bautizado o se preparaban para ello; y la Regla cristiana (1548), para los adelantados o proficientes", Soto Guerrero, La "Iglesia" en los catecismos mexicanos del siglo XVI editados en México, 16.

38 Gerson and Zumárraga, Tripartito del cristianísimo y consolatorio doctor Juan Gerson de doctrina cristiana.

39 From 1524 to 1546 , at least twelve ecclesiastical Juntas (meetings of bishops, provincials of mendicant orders and other prominent Churchmen) were held in Mexico. See Saranyana (ed.), Teología en América Latina, vol. 1, 93-113. It is common to interpret the doctrines as results of the agreements reached by these Juntas as to the way to indoctrinate the natives. Nevertheless, the relationship between the agreements reached by these early meetings of bishops and the catechisms printed in Mexico in the $1540 \mathrm{O}$ and the 155 os is not as clear as the one existing between the later Councils in Mexico and Lima and the official doctrines that were printed afterwards. Only the colophon of the Manual de adultos printed in 1540 states explicitly that the book was financed by the bishops of New Spain and printed by their order, probably following the agreements of the junta of 1539 regarding the way and tools to be used in the catechesis of the natives. "Imprimiose este Manual de Adultos en la gran ciudad de Mexico por mandado de los Reverendissimos Señores Obispos de la Nueva España y a sus expensas: en casa de Juan Cromberger. Agno de nacimiento de nuestro señor JesuChristo de mill y quinientos y quarenta. A. xiii. Dias del mes de Deziembre", Manual de adultos, [n.p.]. See Gil, Primeras "doctrinas" del Nuevo Mundo, 227-229. The other pieces of catechetical literature that are mentioned in this chapter were promoted and financed by the exclusive contribution of Zumárraga, who consequently left his personal and spiritual mark on almost every one of these books. 
capacidad: y que tienen mas necesidad della que de otros sermones que seles predican. ${ }^{40}$

As can be seen, in this first catechetical initiative of 1544 , with the printing of a revised edition of the Caribbean doctrine of the Dominicans, Zumárraga is appealing to the need to avoid fancy and motley sermons in favour of focusing on the main articles of the Christian faith related to God and to the humanity of Christ, the Ten Commandments, the seven sacraments, corporal and spiritual works of mercy, main prayers and the rituals of the sign of the Cross - these being the "simple" but "salvific" contents of this Doctrina cristiana para instrucion $y$ informacion de los indios. The articles of the faith are introduced by a kind of history of the world since its creation. The chronological and logical order of the narrative is intended to facilitate the assimilation of the doctrines by the natives in a rational and coherent manner (not relying only on a dogmatic learning by heart).${ }^{41}$ It is noteworthy that, even if the natives of New Spain were supposed to be more civilised and intelligent than the tainos and other Antillean peoples, ${ }^{42}$ Zumárraga made no distinction between them, taking it for granted that they all had in common a low intellectual capacity, insofar, at least, as catechetical methods and indoctrination strategies were concerned. From his perspective, the "brief and plain" doctrine that Pedro de Córboba "de Buena memoria" and his fellow Dominicans had first taught during the foundation period "de la orden de los Predicadores en las yslas del mar Oceano" was still valid and equally useful and proper for the missionaries in continental America. In this case, there is a perfect convergence between Zumárraga's

40 Córdoba, Zumárraga and Betanzos, Doctrina cristiana para instruciony información de los indios: por manera de historia, colophon [n.p.].

41 Following closely some ideas of Borges, Miguel Ángel Medina also considers this method as according to the oral customs and idiosyncrasy of the natives, whose religious preHispanic life was structured in mythical stories related to the origin of their gods (theogonies) and the world (cosmogonies), Medina, Doctrina cristiana para instrucción de los Indios, 94 .

42 Opting for a methodological uniformity that later missionary agents will criticise. In his De procuranda Indorum salute, the Jesuit Acosta distinguishes among three "classes Barbarorum" according to the degree in which they exercise the "recta ratione" and follow the customs of humankind (law of nations). In Acosta sociocultural hierarchy, Mexicans and Peruvians are at a higher level than peoples considered to be composed of "homines sylvestres, feris similes" such as "Carybes", "Chunchos, Chiriguanas, Moxos, Iscaycingas", "Brasilienses" and natives from Florida. On the other hand, Mexicans and Peruvians are surpassed by the Chinese and Japanese. Acosta suggests a specific missionary approach for each of these levels of civilisation. Acosta, De procuranda indorum salute, "Prooemium", [n.p.]. 
aforementioned passéisme, his admiration for everything that could be considered a founding act and deed, and the increasingly pragmatic attitude that he would develop as a result of the specific missionary challenges he had faced as first bishop in the diocesis of Mexico.

\section{Erasmus' Paraclesis as Pragmatic Manifesto for the Americas: the Doctrina Breve muy Provechosa (1543-1544)}

As previously noted, the Doctrina breve muy provechosa is much longer than the reworking of Pedro de Córdoba's catechetical materials: lengthy explanations of the fourteen articles of the faith, the seven sacraments, the Ten Commandments, another four commandments of the Church and "del derecho comun", the seven mortal sins, the fourteen works of mercy, the five senses and the three faculties of the soul along with their corresponding virtues are included..$^{43}$ Not only the seven sacraments, but also the articles of the faith that, in this period, were discussed by the early reformers or by heterodox Spanish theologians such as Miguel Servet (Mary's virginity and Jesus' conception "sin manzilla por nueva manera de concepción maravillosa y sobre natural", ${ }^{44}$ the Trinity ${ }^{45}$ purgatory ${ }^{46}$ etc.) are explained in detail in this 84 -folio doctrine. ${ }^{47}$

Despite the detailed character of this early Doctrina breve muy provechosa, Zumárraga urges the missionary agents operating in Mexico in a final "Conclusion exortatoria de la obra" to preach the Christian doctrine in the purest and simplest manner, taking the straightforward but salutary and infallible teaching of Jesus as the sole basis of their preaching, and to avoid the subtleties distilled by contemporary theologians and ancient philosophers. ${ }^{48}$ Following the idealised perspective - very widespread at this time - on the self-evident and

43 Zumárraga, Doctrina breve muy provechosa, [n.p.].

44 Zumárraga, Doctrina breve muy provechosa, fol. aIVr.

45 Zumárraga, Doctrina breve muy provechosa, fol. alIIv.

46 Zumárraga, Doctrina breve muy provechosa, fol. aVIv.

47 A full bibliographic record and a very detailed analysis of its structure in Gil, Primeras "doctrinas" del Nuevo Mundo, 313-329 and 388-410.

48 Zumárraga regards with suspicion not only theological and philosophical knowledge, but also that of lawyers and, in general terms, all non-biblical sources. In the Doctrina breve muy provechosa he interrogates his readers in a very rhetorical way: "Porque dan algunos mayor parte de su vida a Avicena: y a Bartolo y Baldo que a los evangelios: Porque casi toda la vida entera de los hombres se gasta en leer scripturas y aprender sciencias y opiniones tan varias de hombres que entre si no concuerdan: $\mathrm{y}$ tan poca utilidad: $\mathrm{y}$ antes prejudiciales y dañosas para el anima", Zumárraga, Doctrina breve muy provechosa, "Conclusion exortatoria de la obra", [n.p.]. 
non-contradictory character of the doctrine of the Gospel, Zumárraga defines this knowledge as a "manjar simplicissimo", which is simultaneously the highest and the easiest one to be learnt from a few books and pure sources:

[...] de unos poquitos libros como de fuentes muy claras la podamos sacar, y esto con muy menos trabajo, que sacariamos la doctrina de Aristotiles: de tantos y tan escabrosos libros: y de tanta multitud de comentarios: de interpretes: los quales jamas en uno concuerdan..$^{49}$

As paragraphs such as this make clear, the pragmatic reasoning of Zumárraga is, in fact, a revision and adaptation to the Mexican missionary context of the famous Paraclesis of Erasmus, the exhortation written by the Dutch humanist in his 1516 bilingual edition (Greek / Latin) of the New Testament. Zumárraga simplifies Erasmus' Paraclesis, removing names and cultural references to Antiquity as well as the history of the Church found in the original text and in the translation into Castilian (1529) attributed to Alonso Fernández de Madrid, ${ }^{50}$ but left intact its spirit.

Transposed into the American context, the original appeal of Erasmus' Paraclesis became even more intense as a kind of pragmatic manifesto wherein "simplicity" and "earthiness" are considered enhancers of a pure truth to be told in plain language comprehensible to the common people:

Lo que principalmente deven dessear los que escriven es que la escriptura sea a Gloria de Jesuchristo: y convierta las animas de todos: y para este efecto ninguna necesidad ay de gentilezas ny retoricas: antes la via mas cierta por donde se alcança esto que yo al presente desseo hazer es por la misma verdad: la qual entonces es de mayor fuerça y vigor quando se dize con mas llaneza y simplicidad. ${ }^{51}$

While Erasmus had insisted on the premise that what could be called pragmatic teaching - a simple and solely Bible-based teaching of the Gospel - was what had permitted - in the time of the Apostles - the triumph of the Church over the Jews and pagans, Zumárraga aimed to transpose this victorious strategy into the new missionary field that was the Americas. Simplification, repetition and the exclusive use of the "plain language" of the Bible, avoiding the

49 Zumárraga, Doctrina breve muy provechosa, "Conclusion exortatoria de la obra”, [n.p.].

50 "Paraclesis", in Erasmus, Enquiridio o manual del cavallero cristiano, 1529. See Martín Abad, La imprenta en Alcalá de Henares, vol. 3, 1364.

$5^{1}$ Zumárraga, Doctrina breve muy provechosa, "Conclusion exortatoria de la obra", [n.p.]. 
subtleties and nuances later introduced by theologians and doctors of other sciences, were, for Zumárraga, not only the tools that Christian Europe needed in its own process of re-evangelisation, but also those which the emerging Mexican Church would have to use in order to succeed in a context of "childlike" neophytes - "pequeñuelos", in the language of Zumárraga and many other churchmen of the time:

[...] esta doctrina de JesuChristo a todos ygualmente se comunica, para los pequeños se abaxa y se haze pequeña conformandose con la capacidad dellos. Cria los como con leche: sufre los: recrea los, sostiene los [...]: porque esta doctrina alos pequeños es muy pequeña: y alos grandes mas que grande: ninguna hedad desecha: ni ningún genero: agora sea de hombre: agora de mujeres: ningún estado: y ninguna manera de gente. ${ }^{52}$

Even if the ideals of Erasmian simplicity and austere piety then in vogue appear as one of the main influences on Zumárraga's missionary strategy, it is important to consider that, within the cultural and religious framework to which Zumárraga belonged - the Franciscan order - Erasmism was probably not perceived as a disruptive innovation. More likely, Erasmus' disciplinary denunciations and apostolic nostalgia were seen by observant Franciscans such as Zumárraga as a reinvigoration of the spiritual current toward a return to the primitive Church that Francis of Assisi himself had supported as a preacher, missionary and reformer. ${ }^{53}$ Within this long-term timeframe, the reputation earned by Erasmus of Rotterdam for wisdom could serve mostly as a learned confirmation of the simple nature of every salvific truth and piece of knowledge that Francis had preached during his lifetime. Assimilated into this longterm perspective, Erasmus' ideas were spread in Zumárraga's catechetical materials, which include not only the cultural translation of the Paraclesis, but also extended quotations and references to the Enchiridion Militis Christiani (1503) and others of Erasmus' writings. ${ }^{54}$

52 Zumárraga, Doctrina breve muy provechosa, "Conclusion exortatoria de la obra", [n.p.].

53 A classic perspective on the impact of the Franciscan spiritual currents in New Spain in: Rubial García, Notas para el estudio del franciscanismo en Nueva España, 1523-1550; For an extensive bibliographic account of Franciscan spirituality on the Iberian Peninsula

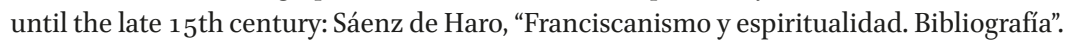

54 On the Erasmian references in the Doctrina breve see Josep Ignasi Saranyana, "El impulso editorial de Juan de Zumárraga y sus denuncias proféticas”, in Saranyana (ed.), Teología en América Latina, vol. 1, 51; Mira Mira, Estudio histórico-genético de la "Doctrina breve" (1543-44) de Juan de Zumárraga. For the Regla cristiana breve, see Alejos-Grau, Juan de 
In his cultural translation ${ }^{55}$ of the Paraclesis, Zumárraga did not limit himself to copying the Castilian translation attributed to Alonso Fernández de Madrid. While rephrasing the ambitious evangelical programme of Erasmus, directed at social groups to this point excluded from the reading and study of the Gospel - especially men from the lowest social classes (farmers, weavers, etc.) and women from every condition - Zumárraga omitted the original references to Turks and Saracens. ${ }^{56}$

Zumárraga, who, as bishop of Mexico, was not especially interested in the Mediterranean infidels, focused instead on the Native Americans as the essential objective of the missionary Church of his time:

No apruevo la opinion de los que dizen que los ydiotas no leyessen en las divinas letras traduzidas enla lengua que el vulgo usa: porque JesuChristo lo que quiere es que sus secretos muy largamente se divulguen, y assi dessearia yo por cierto que qualquier mugercilla leyesse el Evangelio y las Epistolas de San Pablo. Y aun mas digo: que pluguiesse a Dios que estuviesen traduzidas en todas las lenguas de todos los del mundo: para que no solamente las leyesen los Indios: pero aun otras naciones barbaras: leer y conocer: porque no ay dubda sino que el primer escalon para la christiandad es conocella en alguna manera. ${ }^{57}$

Once again, it seems that the paedagogical religious appeals of Erasmus - idealistic to the point of the ridiculous while dealing with the kind of infidels to

Zumárraga y su "Regla Cristiana breve”, 62; Adeva Martín, "Fray Juan de Zumárraga: Regla Cristiana Breve". See also Adeva Martín, "Estudio preliminar".

55 On the concept of cultural translation see Burke, "Cultures of Translation in Early Modern Europe”. Duve and Foljanty have recently recommended the application of the conceptual framework developed by Burke in cultural studies within a juridical-normative perspective Duve, "European Legal History", 29-66; Foljanty, "Legal Transfers as Processes of Cultural Translation: On the Consequences of a Metaphor".

56 According to Erasmus' very idealistic perspective, Muslims could be more easily won over to the Christian cause having access to vernacular versions of the Gospel: "Dessearia yo por cierto que qualquier mugercilla leyesse el Evangelio, y las Epistolas de S. Pablo, y aun mas digo, que pluguiesse a Dios que estuviesen traduzidas en todas las lenguas de todos los del mundo, para que no solamente las leyesen los de Escocia, y los de Hibernia, pero para que aun los Turcos y los Moros las pudiessen leer y conocer, porque no ay duda, sino que el primer escalon para la Christiandad, es conocella en alguna manera", "Paraclesis", in Erasmus, Enchiridion o Manual del Cauallero Christiano de D. Erasmo Roterodamo en romance, 1555 , fols. $193^{-1}-193 v$.

57 Erasmus, Enchiridion o Manual del Cauallero Christiano de D. Erasmo Roterodamo en romance, 1555, "Paraclesis". 
be found in the European context of his time - is better suited to the Mexican context than to their original setting. While Jewish and Muslim rejection of the Christian religion could not be primarily considered as resulting from a lack of knowledge, but rather as a conscious opposition to a rival creed - an element that undermines the applicability of Erasmus' proposals in the European context - most of the Amerindian nations did not demonstrate any kind of open hostility to Christianity. As the theologians of this period stressed, ${ }^{58}$ urging warlords to distinguish among types of infidels, native Americans were not open enemies of the Christian religion, but suffered instead from an invincible ignorance of the evangelical truth. Their infidelity was not, therefore, to be punished or fought, but rather cured with appropriate remedies. The translation of previous European catechetical materials and the publication of new doctrines in the languages of the Mexican natives - an initiative also launched by Zumárraga during his lifetime - figure among these remedies and are clearly related to the flourishing printing of this kind of pragmatic literature in the vernacular languages of the Americas.

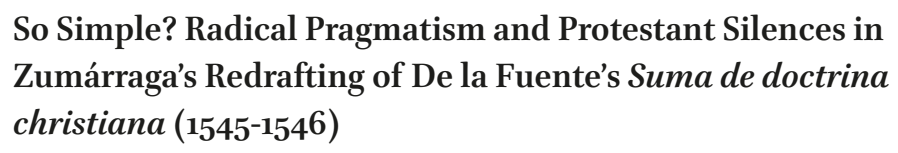

Zumárraga's utopian republic of readers can be considered one of the attempted missionary strategies that the Roman, Spanish and American Church would discard not only within the context of the New World, but also with regard to the Iberian worshipers. ${ }^{59}$ From the second half of the sixteenth century, other approaches would prevail, while the scriptural fixation of Zumárraga and other Erasmian churchmen too close to the Protestant sola Scriptura motto would be increasingly regarded as suspicious and untenable.

Among the first Spanish writers of catechetical literature to be arrested, put on trial and condemned by the Inquisition because of such a scriptural approach (in the years $155^{-1560}$ ), the figure of Constantino de la Fuente, canonmagistral of the cathedral of Seville and court preacher, appears to be closely linked with the missionary perspective of Zumárraga. His life and writings have

$5^{8}$ Since the pioneer treatise De dominio Regum Hispaniae super Indos (1512), written by the Dominican friar Matías de Paz. Paz, Del dominio de los Reyes de España sobre los indios, 221.

See Rodríguez, El Catecismo romano ante Felipe II y la Inquisición española, 148-180. 
been well studied in abundant and sometimes contradictory - with regard to the religious adherence of De la Fuente - literature ${ }^{60}$ For present purposes, it suffices to note that, before his fall from grace, he was the most prolific author of catechetical books in the Spain of his time. ${ }^{61}$

As is well known, among the doctrinas printed by Zumárraga in Mexico, there is also a kind of redrafting in a non-dialogical way of the Suma de doctrina christiana (1543) that Constantino de la Fuente had published three years before in Seville. ${ }^{62}$ Zumárraga re-edited this Suma twice. In $1545^{-1546, ~ h e ~ e d i t-~}$ ed De la Fuente's Suma with almost the same title ${ }^{63}$ and without major modifications (apart from the minor changes stemming from the adaptation of De la Fuente's dialogical catechism into a monologue, which is characteristic of the doctrines). In 1546, this first re-edition of De la Fuente's catechism was, in turn, re-edited by Zumárraga. A Suplemento of 38 pages was added to the $1545^{-46}$ edition. It is highly probable that, because of the notorious dogmatic and disciplinary omissions in De la Fuente's catechism to be analysed hereinafter, Zumárraga decided to address them directly, reducing some of the most important gaps and anticipating any kind of future criticism or censorship. The exact differences between these two Mexican re-editions of De la Fuente's catechism are not completely clear. The uncertainties regarding them will probably never be resolved owing to the loss in transit from Toledo to Madrid of the only copy of the 1545-46 edition. Nevertheless, according to the Mexican scholar and bibliographer García Icazbalceta, who acquired a transcription of some paragraphs of the preface, the colophon and the title sections of the book printed in $1545^{-46}$, there is some evidence that it was almost identical to

6o A recent overview of his writings and the literature on his person in Giesen, "Audacia y precaución".

61 Wilkinson lists the following titles: Suma de doctrina christiana en que se contiene todo lo principal y necesario (Seville, 1543, 1544, 1545, 1551; Antwerp, [1549]); Catecismo cristiano (Seville, 1547; Antwerp, 1556); Doctrina christiana. Parte primera. De los artículos de la fe (Seville, 1548); Doctrina christiana en que esta comprehendida toda la informacion que pertenece al hombre que quiere server a Dios (Antwerp, 1554-1555). Apart from these doctrinas, the rest of De la Fuente's literary production is also to be assigned to close subgenres of religious indoctrination, sermons and commentaries on Biblical psalms: Sermon de nuestro redentor en el monte (Seville, 1543, 1545 - edited together with the Suma de doctrina christiana); Exposicion del primer psalmo de David (Seville, 1546, 1548); Exposición del salmo "BeatusVir" (Seville, 1547); Exposicion del primer psalmus de Daniel (Antwerp, 1556), Wilkinson (ed.), Iberian Books, 587-588.

62 De la Fuente, Suma de doctrina christiana.

63 Zumárraga, Doctrina cristiana: en que en suma se contiene todo lo principal y necessario que el cristiano debe saber y obrar. 
the 1546 edition. ${ }^{64}$ It seems that the only substantial change was the Suplemento and that Zumárraga opted for this kind of ad hoc tool instead of modifying or correcting De la Fuente's text line by line.

The sources, key ideas and, especially, De la Fuente's / Zumárraga's doctrinal omissions make these books much more problematic than the previous doctrines. The apologetic simplicity found in previous catechetical editions of Zumárraga are taken with these re-editions to an extreme in which it is difficult to distinguish the aforementioned pragmatic ideals from a conscious attempt to erase part of the dogmatic and disciplinary patrimony constructed by the Roman Church over centuries.

Omissions, silences and what a zealous reader could consider a contradiction or false expectations while contrasting the promissory title of the books which explicitly indicates that it "contiene todo lo principal y necesario que el hombre cristiano debe saber y obrar" - and their de facto contents are at the core of the criticism aroused by De la Fuente's catechism. ${ }^{65}$ It is probable that Zumárraga's doctrine also met with similar reproaches. It would be otherwise difficult to explain why, at the end of 1546 , little after its first printing, Zumárraga felt himself compelled to prepare and order the printing of a second, revised edition of this same book. In any case, those precautions were not enough to put an end to any probable suspicion. It is, in fact, known that Zumárraga's unabashed enthusiasm for Erasmus and his call to translate the Bible into every language in the world attracted the attention of his follower in the archbishopric of Mexico, Alonso de Montúfar, who in November of 1559 - this same key

64 Contrasting the information he had received from one of his informants in Spain, Icazbalceta considered that, apart from the Suplemento, there was only a minor change a slight rewording - in one of the paragraphs of the Preface. The contents of the two doctrines were laid out in the same order and even the foliation coincided, García Icazbalceta and Millares Carlo, Bibliografía mexicana del siglo XVI, 74-75.

65 The scholars who have dealt with the catechetical writings of De la Fuente himself, have been traditionally divided between those who consider this famous theologian and orator of 16th century Spain as a closet Lutheran (following the influential interpretation of Menéndez Pelayo and his Historia de los heterodoxo sespañoles), and the historiographical current which, taking into account the famous findings of Marcel Bataillon in his Érasme et l'Espagne, considers De la Fuente, Egidio and other Spanish heterodox religious thinkers of this time closer to Erasmus' ideas and followers of previous Spanish spiritual trends, the movement of the alumbrados being the most closely related. Among the most recent accounts on these conflicting interpretations: Pastore, Una herejía española. As it is the case for the debates concerning Zumárraga, such labelling and judgments reviewing are quite sterile. A fluid circulation of religious ideas culturally translated into different regions seems to be the dominant note until the end of the Council of Trent and the consolidation of the Christian schism. 
turning point in the lives of De la Fuente and Carranza - was able to have those books condemned via a meeting of theologians held in Mexico. ${ }^{66}$

What De la Fuente considered the "breve sciencia" by which both learned and unlettered men had to abide in order to obtain salvation ${ }^{67}$ was limited to the symbol and the articles of the faith, the Ten Commandments, the proper way to pray and some of the sacraments (baptism, penance and communion). De la Fuente's Suma does not mention the sacraments of confirmation, extreme unction, holy orders and marriage. The catechetical approach of the Sevillian canon-magistral implied a clear break with the systematic expositions of the seven sacraments that had become well established after Radulphus Ardens' Speculum universale (11th century), Peter Lombard's Liber Sententiarum (12th century), Aquinas' Summa Theologiae (13th century) and the conciliar validation of their positions in the Second Council of Lyons $(1274)^{68}$ and the later Council of Florence (1439). ${ }^{69}$

The exposition of the ninth article of the faith in the Suma, regarding belief in the Holy and Catholic Church could also lead to confusion and give rise to misunderstandings. The hierarchical structure of the Church is something that does not seem to be of interest to De la Fuente. The Church is defined as the "congregation" of the worshipers or as the "mystical body" that they form together with their head, Jesus Christ. With regard to the internal order of this Church, De la Fuente recognised only Christ as "cabeça" and established a minimal difference between "those who serve God" and other Christians. ${ }^{70}$ The Pope is therefore another of the great absentees from the Suma and later from

66 AGN, Inquisición, vol. 43, exp. 4; Libros y libreros en el siglo XVI, ed. Fernández del Castillo, "Censura y prohibición de la Doctrina cristiana del Ilustrísimo Don Fray Juan de Zumárraga Obispo de México (1559)", doc. II, 1-2. Nesvig analysed this process in his book, but made a mistake when identifying the book(s) that were condemned by this Mexican junta, see Nesvig, Ideology and Inquisition. The World of the Censors in Early Mexico, 120-123. A later document from the Spanish Inquisition ("Libros mandados recoger en cumplimiento del Breve de Gregorio XIII de 1573", 1574, doc. X, 246) clarifies the matter and helps to discard other information provided by Nesvig, who erroneously states that the prohibition of Zumárraga's doctrine remained in force until 1579. As can be seen, the Doctrina christiana was in circulation again in the territory of New Spain from at least 1574 .

67 "A esta breve sciencia se han de atener y con ella se han de salvar los profundos y muy fundados letrados. Y estas letras es menester que sepan sino se quieren perder los rusticos y simples hombres del mundo", De la Fuente, Suma de doctrina christiana, fol. tvr.

68 Neusner and Dupuis (eds.), The Christian Faith in the Doctrinal Documents of the Catholic Church, 19 .

69 Bornstain, "Administering the sacraments"; Pardo, The Origins of Mexican Catholicism, 11-14.

70 De la Fuente, Suma de doctrina christiana, fols. lvv-lviiiv. 
De la Fuente's doctrines. Systematic expositions regarding virtues and sins, weaknesses of body and soul and their corresponding works of mercy are also lacking in a catechism where the doctrine of justification by faith alone is stated with a certain rhetorical caution. ${ }^{71}$

As is to be expected, the explanation of the nature and meaning of the Mass is placed by De la Fuente outside the chapters dedicated to the sacraments. It is to be found later in the fifth and final section of the book. ${ }^{72}$ With it being confined to a marginal position, the attentive reading of previous paragraphs of the Suma indicates that De la Fuente writes about the Mass reluctantly and in order to avoid immediate and certain scandalum. ${ }^{73}$ Detached from the sacrament of the Eucharist, the Mass appears as a mere "representacion de la passion del redemptor del mundo". The transubstantiation or real presence of the body and blood of Jesus Christ is not mentioned or insinuated at all. With the Mass now deprived of its transcendent significance, the reading of the "doctrina de la epistola y del evangelio"74 grows in importance. According to this translatio studii, the religious orientation provided by De la Fuente is concerned with the care and attention with which the worshipers are to hear the Mass. De la Fuente even recommends a previous individual or group reading "en romance" of the Biblical paragraph and epistle read during the Mass the following day. ${ }^{75}$ The scriptural orientation of its teaching - very close, as noted, to Zumárraga's missionary perspective - is evident. From a philosophical and epistemic point of view, a translatio sensuum is also something to be considered. Hearing and sight replace the tasting experience associated with the Mass and with the sacrament of communion, an experience that orthodox catechisms regulated explicitly. ${ }^{76}$

71 For example, in the exposition of the first article of the faith: "De aquí es que quien yerra enlo principal dela fe, que es el verdadero conoscimiento de Dios, y en sentir verdadera y acertadamente del y de sus obras, va perdido, porque ha errado la puerta, y ningún camino ay, por donde no se pierda ni obras por donde se salve", De la Fuente, Suma de doctrina christiana, fol. xviiir.

72 De la Fuente, Suma de doctrina christiana, fols. †ivv-\$vr.

73 "Ambrosio: [...] Esta es la doctrina que mi maestro me dio acerca de este sacramento. Dyonisio. Bien se pudiera alargar enella y no se perdiera nada: mas su tiempo se verna. $Y$ mucho mas aveys dicho de lo que pensays: porque vuestro maestro quiso daros essa materia, en que andando el tiempo vereys que teneys bien que pensar", De la Fuente, Suma de doctrina christiana, fol. clxr.

74 De la Fuente, Suma de doctrina christiana, fol. clxv.

75 De la Fuente, Suma de doctrina christiana, fols. clxv-clxir.

76 This is the case in Ripalda's famous catechism. Here, the "manjar espiritual" is no more the salvific knowledge of the Bible - as was it in the case of Erasmus, De la Fuente and Zumárraga - but the body and blood of Jesus Christ that the worshiper received in 
Interestingly, while presenting his catechism in the prefatory letter addressed to the archbishop of Seville, García de Loaysa, De la Fuente appealed, precisely, to the need to be pragmatic - that is to speak "plain" and "simple", in the language of his time ${ }^{77}$ - in order to transmit to the common man what was strictly necessary for salvation and to reach a wider illiterate public.

De la Fuente seems to rely, in fact, on pragmatism in order to justify a choice of the ingredients for redemption very similar, in fact, to the recipes that Luther and Calvin ${ }^{78}$ - authors of relatively similar catechisms - had devised, appealing not only to these practical criteria, of lesser interest to both of them, but as an expurgatory and vehement denunciation of what they considered Roman adulterations of the ancient traditions and pure doctrine of the Church. For obvious reasons, this kind of criticism is mentioned only in passing in De la Fuente's introductory letters, almost completely reproduced in Zumárraga's Doctrina cristiana mas cierta y verdadera:

Esta doctrina porque nadie la menosprecie ni tenga en poco: es la que la yglesia catholica en su principio enseñó con grandissimo cuidado a sus hijos. Esta era la predicacion de entonces: y lo que en las publicas y particulares congregaciones se trataba del negocio de JesuChristo redemptor y segnor del mundo. Aquí esta summado y recolegido todo lo que esta sembrado por las escripturas divinas $[\ldots] .{ }^{79}$

The last sentences lead the reader to consider De la Fuente's catechism as a kind of epitome of the Holy Scriptures themselves, the truth of which is not only distilled from the "ceguedades" and "variedad de docrinas" introduced

"real substancia" taking Communion, Ripalda, Doctrina christiana, con una exposición breve, 27-28.

77 "Doctrina es llana y para gente sin erudicion y letras: mas cierta y verdadera: y el tesoro con que se gana el cielo", De la Fuente, Suma de doctrina christiana, fol. \$iiiv.

78 As does De la Fuente, they deal only with some of the sacraments: baptism and communion. Luther, Der Kleine Catechismus; Calvin, Instruction \& confession de foy, dont on use en Leglise de Geneve.

79 De la Fuente, Suma de doctrina christiana, fol. \&vr. And later on, in paragraphs full of double meanings, which reveal a high degree of self-restraint and self-censorship: "Vengamos al remedio desto: si remedio se puede decir tan blanda medicina como es la que quiere el mundo para tan grandes y tan envegescidas llagas como son las que tiene. Siempre le es cosa aspera y escandalosa dezirle que vuelva ala virtud antigua [...]. Dexemos pues por cosa enojosa y demasiada el verdadero remedio: vengamos a otros mas faciles", fols. tviv-tviir. 
later by the "sectas y titulos de theologos" mentioned by De la Fuente shortly after, ${ }^{80}$ but also extremely condensed.

Depending on the importance given to the institution of the Papacy, to the missing sacraments or to the aforementioned division between the ceremony of the Mass and the sacrament of the Eucharist, the scholars examining De la Fuente's writings have considered his silences and expository choices as "weak points" 81 in his catechetical writings or, more harshly, as scattered notes of an "underhand and skilful Lutheranism". 82

The predominant trend in contemporary historiography is to consider the doctrines written by De la Fuente and other related theologians as books perfectly suited to the period in which they were written, that it is to say, for the 153 Os and the 1540s, becoming problematic thereafter. From this perspective, De la Fuente and the sympathisers and emulators of his catechetical perspective would have been the victims of the increasing rigour and harshness exerted by the Spanish Inquisition and the Roman Church from the late1550s onwards, especially, after the conclusion of the Council of Trent (1563). The anathemas of Trent would have led to the marginalisation of certain theological approaches, which previously were not only tolerated, but also enjoyed great acceptance. ${ }^{83}$

This historiographical hypothesis seems to contradict the way in which contemporary readers noticed and, sometimes denounced, what they considered as inexcusable omissions. In the case of De la Fuente's doctrines, the Spanish Archivo Histórico Nacional holds two reports that the Inquisition commissioned in 1556 to the Flemish Dominican theologian Jean Hentenius ${ }^{84}$ and to another unnamed consultant. ${ }^{85}$ Both reports contained similar denunciations of what was considered deliberate ambiguity on the part of De la Fuente regarding almost every one of the doctrinal and disciplinary points disputed with Luther and his followers. ${ }^{86}$ Another parecer of 1557 , perhaps written by Juan de Ovando, provisor of the archbishopric of Seville in the 1550s - and later president of the Council of the Indies - or some of the theologians who were close to him and to the Inquisidor general, Fernando de Valdés, condemned harshly the Suma de doctrina christiana and pointed out that De la Fuente's silences and rhetorical juggling were particularly inappropriate and inexcusable in the catechetical literary genre ("linaje de escriptura"):

\footnotetext{
8o De la Fuente, Suma de doctrina christiana, fol. \&vv.

81 Guerrero, Catecismos españoles del siglo XVI, 307.

82 Resines Llorente, Catecismos americanos del siglo XVI, vol. 2, 417.

83 Pastore, Una herejía española, 310-313.

84 AHN, Inquisición, Leg. 444, no. 5 .

85 AHN, Inquisición, Leg. 444, no. 49.

86 Aspe Ansa, Constantino Ponce de la Fuente, 97.
} 
Item que en estos tiempos en cosa tan importante no basta no dezir la heregía contraria, sino es neccessario dezir la verdad cathólica como contra Erasmo dixo bien Alberto Pío. Item que ya que esa escusa se admitiera en otro linaje de escriptura y de escriptor, no en esta scriptura que él llama Summa de doctrina christiana, en que se contiene todo lo principal y lo neccessario quel hombre christiano deue saber y obrar, y a un escriptor que tan grande cosa promete en el principio. $Y$ en el fin recapitulando dize: «Con la mayor breuedad que nos fue possible comprehendimos en esta summa todo lo principal y lo neccessario que la doctrina christiana contiene» etc. ¿Qué cosa más principal o más neccessaria para el christiano que saber y tener entendido que ha de estar debaxo de la obediencia de la iglesia cathólica, y que la cabeca desta es el papa, successor de san Pedro y bicario de Jesuchristo; y tener entendido que lo que esta iglesia le enseñare es lo verdadero, y que aquellos son los libros de diuina scriptura que esta iglesia señalare por tales, y que aquél es el verdadero sentido de todos ellos y de qualquiera par[te] dellos, que esta iglesia aprobara y diere por verdadero sentido; $y$ todo lo que ella reprobare y diere por falso, es falso y digno de ser reprobado? Éste es el fundamento primero y el A.b.c. de la doctrina christiana, del qual ninguna mención haze este señor. ${ }^{87}$

It can be inferred from the three reports mentioned above that the kind of radical pragmatism and simplicity advocated and recommended by De la Fuente to priests and householders was not unanimously accepted. On the contrary, by $155^{6-1557}$, Hentenius and other theologians considered this catechetical perspective as a clear attempt at expurgation of the patrimony of the Church, closely linked to some of the explicit attacks initiated by Luther and other reformers.

\section{Approaching Heresy without Falling into It. Zumárraga's Additions and Supplements to the Problematic Doctrines of Córdoba and De la Fuente}

What relevance has the American contemporary missionary literature for this intra-European, intra-Spanish and, somehow, intra-Sevillian bitter doctrinal dispute, which, as with many other theoretical quarrels, also covered a struggle for power and influence? The kind of dogmatic and practical

\footnotetext{
87 "Parecer" transcribed and published by García Pinilla, "Más sobre Constantino Ponce de la Fuente y el Parecer de la Vaticana (Ms. Ottob. Lat.789)", 213-214 quoted. The title of the article is slightly wrong. The "Parecer" is to be found in Ms. Ottob. Lat. 782.
} 
misunderstandings that could arise from the excessive - and sometimes intentional - simplicity of many catechetical materials and exposition models which had circulated for decades in and around Iberia ${ }^{88}$ but which became problematic in the new context of a multi-confessional Europe, did not go unnoticed by Zumárraga. Even if his biographers ${ }^{89}$ said nothing about his training, or merely supposed that he received only a modest theological education before or after his time as a Franciscan friar, in fact the bishop of Mexico was anything but ignorant or naïve..$^{90}$ The troublesome dogmatic perspectives and especially the problematic silences to be found in De la Fuente's Suma de doctrina christiana, which would rouse suspicion over the orthodoxy of both book and author ten years later in Spain - leading ultimately to the post-mortem condemnation of De la Fuente as "hereje dogmatizante" in an auto-da-fe held in Madrid in $156 \circ^{91}$ - had already been detected by the attentive Zumárraga. In order to avoid any kind of suspicions and accusations, shortly after the printing of the Doctrina cristiana - which, as noted, reproduces De la Fuente's Suma without significant changes - Zumárraga published a conscious Suplemento of forty pages filling almost every one of the dogmatic and disciplinary gaps that De la Fuente had left open.

The strategy of taking, as a starting point, very simple materials and clarifying them with ad hoc additions, confusing paragraphs, missing references to important dogmatic elements or any kind of lacuna that could lead to a disciplinary deviation is not new in Zumárraga's catechetical production. There is ample evidence that Pedro de Córdoba's succinct doctrine was also intensively

88 A useful overview of the extensive Iberian production of catechetical literature in the 15th and 16th centuries is Sánchez Herrero, "Alfabetización y catequesis en España y en América durante el siglo XVI".

89 They do not seem to have discovered much about his obscure childhood and youth since García Icazbalceta's pioneering work. Icazbalceta was astonished by the great mysteries regarding his birthplace, date of birth, the monastery where he took the cloth and his studies, see García Icazbalceta, Don Fray Juan de Zumárraga. Primer obispo y arzobispo de México, vol. 1, 13-14.

9o Interpreting Zumárraga's education under the classic glasses of the Manichean division between the Middle Ages / Renaissance, ignorance / wisdom, light / darkness, etc., Greenleaf considered the bishop as "a man of contradiction, a segmented thinker", stating that "although he professed to be a Christian humanist and exhibited an affinity for the ideas of Erasmus, Zumárraga was bound by Thomist orthodoxy. In fact, early sixteenthcentury Mexico did not belong to the Renaissance but Dante's World Empire", Greenleaf, Zumárraga and the Mexican Inquisition, 1536-1543, 41, 131. Beyond this kind of anachronistic stereotypes, it would be hard to identify which should be the elements of Thomist orthodoxy in Zumárraga's religious thought.

91 Luttikhuizen, Underground Protestantism in Sixteenth Century Spain, 12-13, 200-211. 
reworked by Betanzos and Zumárraga before its 1544 publication. Even if it is an impossible task to work only with tentative hypotheses - because there is no previous printed edition nor an original manuscript of Córdoba's doctrine Durán and Medina ${ }^{92}$ have identified some clear adaptations to the Mexican missionary context. Scattered throughout the text, those additions are related to the Aztec gods, cults and rites.

The additions that are of interest for the purposes of this contribution are those related to the doctrinal points that were barely mentioned in or altogether absent from the main body of the doctrine. The first has to do with purgatory. The existence and nature of purgatory, which was mentioned in passing in a passage about praying for the deed as a work of mercy, seems to have been clarified by Zumárraga / Betanzos. In fols. dr-dv of their rewriting a detailed topography of the four parts of hell - hell proper, purgatory, hell, a place where the righteous who preceded Jesus were - is provided, while the existence of the souls in purgatory is described and the utility of "alms", "fasts" and "prayers" for friends and relatives - highly criticised by the reformers - is stressed.

A second doctrinal addition (in fols. dv-diir) consists of a reaffirmation of the dogma of Mary's virginity before and after the conception and birth of Jesus. Mary is considered in this paragraph an example, virginity a "great good" in and of itself and a feature which distinguished "clean" women and men from "dirty" lustful individuals. The insistence on Mary's virginity, which had already been mentioned in the exposition of the articles of faith, and this new approach toward some of its moral implications should also be seen as a kind of unsolicited reaction to the Protestant attacks on these dogmatic and moral points.

The third doctrinal addition is an elaborate definition of the Church as "cuerpo mistico" and "ayuntamiento" of the Christian faithful ruled over by the Pope, successor of Saint Peter and Jesus Christ. Such a definition was obviously missing in the catechism written by Luther, Calvin and other reformers. ${ }^{93}$ It was also missing, as noted earlier, in De la Fuente / Zumárraga's Suma and, as it implies relatively complex political thought and vocabulary, the early American doctrines seem to have avoided getting into details ${ }^{94}$ on this matter to

92 In their almost identical evaluation of the "Mexican" additions to the Doctrina christiana para instrucion de los indios (1544), Guillermo Durán, Monumenta catechetica hispanoamericana (siglos XVI-XVIII), vol. 1, 209-213; Medina, Doctrina cristiana para instrucción de los Indios, 106-111.

93 See, for example, Calvin, Instruction \& confession de foy, dont on use en Leglise de Geneve, 58-59.

94 Speaking about the Instrucción de la orden que se ha de tener en la doctrina de los naturales, written by Bishop Jerónimo de Loayza (1545) in the early Peruvian Church, 
the point of having ignored it completely. The high accuracy with which this matter is addressed in the additions to the Doctrina christiana para instrucion de los Indios (1544) and the explicit condemnation as heretics of those not recognizing and obeying the authority of the Pope ${ }^{95}$ should also be considered against the backdrop of the ongoing debates in Europe throughout this period. It is, incidentally, somehow curious that heretics were gravely threatened in the doctrine, the authors all the while failing to define heresy - another very complex term - anywhere in the entire book.

The Suplemento of $1546^{96}$ is also a highly revealing indicator of the antiLutheran or anti-Protestant campaign that began to influence the writing of catechetical materials for the New World almost from the very beginning of the first systematic and serious attempts to indoctrinate the natives with the Christian faith.${ }^{97}$ Not by chance, the first paragraph added to the controversial, minimalistic doctrine of $1545^{-1546}$ is an explicit expression of commitment to the authority of the Church and to the decisive and binding character of its determination in matters of faith. According to Zumárraga, a full subjection to the authority of the Church was especially important for those "simple persons, who cannot understand every one of the things that the Church believes". ${ }^{98}$

Estenssoro identified similar important doctrinal gaps: "No se trata de la Trinidad bajo ningún aspecto, ni se mencionan jamás los nombres de Cristo, Jesús o María, no se habla de la Iglesia", Estenssoro, Del paganismo a la santidad, 56 .

95 "Y despues que murio san Pedro: los christianos eligieron otro, y assi en muriendo uno luego elijen otro. Y este que assi es elegido para que govierne la iglesia llamase Papa. Y esta en una ciudad que se llama Roma: y no ay mas de un Papa en el mundo. Y a este emos de obedecer todos los Christianos. El que no tiene al Papa por cabeça y regidor de la iglesia, es herege. Y a este tal hanlo de quemar en el fuego", Córdoba, Zumárraga and Betanzos, Doctrina cristiana para instrucion y información de los indios: por manera de historia, fol. diiv.

96 Zumárraga, Juan de, "Suplemento del catecismo o enseñamiento del christiano: con las adiciones que parece que le faltavan. Porque sea doctrina entera y aya conformidad y uniformidad en su enseñamiento". In: Zumárraga, Doctrina cristiana: mas cierta y verdadera para gente sin erudicion y letra, fols. livv-nviiir.

97 A detailed analysis of the contents of this Suplemento in Guillermo Durán, Monumenta catechetica hispanoamericana (siglos XVI-XVIII), vol. 2, 206-110. Durán's analysis lacks an interpretation of the materials added by Zumárraga with regard to the European debates between Catholics and Protestants. Following a widespread attitude in LatinAmerican historiography, the contents of the Suplemento are interpreted taking only into account their "utility" or role in the missionary context of the Indies.

98 "Son obligados los que son christianos o lo quieren ser a creer lo que cree y tiene la sancta iglesia catolica romana [...]. E assi es de saber que las personas simples que no pueden alcançar a saber todo lo que cree la iglesia: desseando y procurando de saber lo, en tanto que no lo alcançassen: bastaria para su salvacion creer como es dicho firmemente y sin 
Thinking most probably of the indigenous people under his jurisdiction and pastoral care, Zumárraga did not consider a comprehensive knowledge of the Christian faith necessary for salvation. As he states in the Suplemento, for these kinds of cases, obedience and acceptance of the Church's criteria were sufficient to obtain salvation.

Zumárraga presents, secondly, a brief overview over some of the most important Christian ritual elements: the meaning of the image of the Cross, instructions on how to cross oneself, the main prayers, attitude and the positions of the worshipers during the Mass. He probably deemed it a useful addition to the original doctrine not only because of the unfamiliarity of the natives to these religious practices newly introduced by the Spaniards, but also because De la Fuente, focusing only on the evangelical-readable part of the Mass, had completely neglected the purely ritualistic facets of the ceremony.

As might be expected, a third addition consists of an explanation of the kind of reverence that Christian worshipers should show for images of the Holy Cross, the Virgin Mary and the saints. Zumárraga addresses explicitly the native worshipers, to whom he wants to explain the difference between an idolatrous adoration per se of objects and creatures such as that practised "in this land", and Christian veneration. Zumárraga also explains the proper hierarchy of the images according to what they represent. Even if saints come last in this ranking, the bishop considers it important to have images of a saint - an object of special devotion - in the home "rezar le cada dia alguna oración y el dia de su fiesta hazer algo por su servicio". ${ }^{99}$ Although only the natives and the traditional Mexican idolatries are mentioned in this part of the Suplemento, it is clear that the long explanation regarding the images intends to fill a notorious void in De la Fuente's doctrine. It can be seen as a counter-reformist defence of Catholic piety taking place, interestingly, long before the conclusion of the Council of Trent. Once again, motivations stemming from the European debates and from the American missionary context meet in a paragraph well worthy of a second glance.

After a half-page dedicated to morning and evening prayers, which the worshiper was to repeat upon rising and before going to bed, Zumárraga attempts to remedy another of the most flagrant omissions in De la Fuente's catechism and introduce a systematic exposition of the seven sacraments in seven pages. In this part of the Suplemento, he is guided by the classical order

duda alguna lo que tiene la sancta iglesia y rogar a nuestro señor que los alumbre en la fe de los christianos: y esto se debe mucho encomendar a la memoria y dezir cada uno muchas vezes entre si mismo", Zumárraga, Suplemento, fol. lvr. 
of exposition found in such writings as the Speculum universal of Radulphus Ardens (c. 1200), ${ }^{100}$ an established canon whom he had also followed carefully while rewriting Pedro de Córdoba's doctrine. In the long tradition from Ardens to late mediaeval doctrines, sacraments were differentiated according to their necessary or voluntary nature. The common order of exposition - also found in this work of Zumárraga - is as follows: baptism, confirmation, Eucharist, penance, extreme unction (necessary sacraments), holy orders and marriage (voluntary sacraments). Trying to avoid any kind of misunderstanding with regard to the sacraments, Zumárraga also went beyond the previous brief doctrine taken from Pedro de Córdoba and gave further precisions for sacraments such as confirmation, extreme unction and the holy orders, previously epitomized in only one line. ${ }^{101}$ Considering the quantity of information on the sacraments, the catechetical approach of the Suplemento could be considered as an intermediate position between the very minimalistic explanations of Pedro de Córdoba's and Constantino de la Fuente's rewritten catechisms and doctrines for proficient worshipers such as the Doctrina breve muy provechosa (1543-1544) and the later Regla cristiana breve (1547).

The moral sections that follow the doctrinal exposition of the sacraments in the Suplemento are much shorter and give the impression of being a mere stopgap and formal solution to the suppression of the classical explanations regarding powers and enemies of the soul, sins, theological and cardinal virtues and works of mercy in De la Fuente's catechism. The epitomisation process of erudite theological doctrines reaches an extreme when Zumárraga addresses these issues. Here, the reader of the doctrine does not find any kind of doctrinal or moral explanations, but only a conceptual scheme. For example:

Potencias del anima, y enemigos del anima, y los tres estados.

Otras cosas ay que debe saber, y son las siguientes. Las potencias del anima son tres, memoria, entendimiento, voluntad. Los enemigos del anima son tres. El demonio, el mundo, la carne. Los estados son tres. Casado bueno, biudo mejor, virgines muy mejor.

100 Bornstain, "Administering the sacraments", $133^{-134 .}$

101 "El segundo sacramento es Confirmación, que se da para que el christiano sea mas fuerte y firme en la fe, y para mayor Gloria [...]. El quinto es Extrema unción. Este sacramento se da alos que se quieren morir, y vale mucho para el perdón de los pecados. El sexto sacramento es Orden. Esta orden se da alos que han de ser ministros dela yglesia, y han de decir missa, y administrar los otros Sacramentos", Córdoba, Zumárraga and Betanzos, Doctrina cristiana para instrucion y información de los indios: por manera de historia, fols. ciiiiv-cvr; fol. cviiv. Such an extreme epitomisation could give rise to misunderstandings. The nature and implications of extreme unction seem particularly confusing in this abrupt overview. 
El pecado se comete en tres maneras, por el pensamiento, por la palabra, por la obra. Tres maneras ay de peccados, mortal, venial, original. Pecado mortal es por el qual el que lo comete es obligado al infierno sino haze penitencia del, por el venial al purgatorio, por el original al limbo. ${ }^{102}$

Zumárraga's problem was not the moral dimension of the Christian religion per $s e$, but very likely rather the conceptual-rationalistic manner in which it had been taught since the time of Radulphus Ardens. This becomes evident in the last part of the Suplemento that shows, moreover, that his final objective was not to provide a highly condensed doctrine. In contrast to the extreme abridgement of the classical schema of virtues, sins, works of mercy, etc., in the following nineteen pages - half of the Suplemento - which form the second part of the document are found six moral texts in which Zumárraga addresses at length moral points that, although not indispensable, ${ }^{103}$ were of particular interest to him. The first three documents, presented under the subtitle "Documentos para adquirir estado de gracia" are moral reflections addressed by Zumárraga to confessors and sinners who want to do penance, prepare themselves to confess their sins or try hurriedly to "remediar y ordenar su alma"104 preceding an imminent death. Beyond its being an exhaustive manual for confessors and penitents, it is also a kind of Ars moriendi in which Zumárraga stresses the salvific value of two spiritual operations: the rigorous examination of conscience and sincere contrition.

Close to Erasmus' famous De praeparatione ad mortem (1534) in his detachment from any kind of theological speculations, his encouragement of an examination of conscience driven "por el amor de dios principalmente y no por el temor de la muerte"105 and his focus on the spiritual preparation for death while the sacramental aid of extreme unction is neglected, ${ }^{106}$ Zumárraga was also influenced by previous writers of this genre such as Gerson, whose Opus tripartitum - in Castilian translation ${ }^{107}$ - is explicitly and extensively

\footnotetext{
102 Zumárraga, Suplemento, fol. miiv.

103 Perhaps important for Christian religion, but not necessarily to be found in this kind of catecismos breves.

104 Zumárraga, Suplemento, fol. mviv.

105 Zumárraga, Suplemento, fol. mviv. Both Zumárraga and Erasmus avoided the traditional frightening representations of death and the after-death judgment.

106 See Pabel, “Humanism and Early Modern Catholicism", esp. 32-33.

107 The Opus tripartitum, written in the early fifteenth century by Jean Gerson, was first published in Castilian in the translation of Juan de Molina: Gerson, Confesionario. Wilkinson lists eight editions of the Confesionario or Tripartito of Gerson in the Iberian context, among them the one prepared and financed by Zumárraga in Mexico (1544). Wilkinson (ed.), Iberian Books, 375 .
} 
paraphrased as "confirmación de lo sobredicho"108 (in the fourth moral text). The same moral and religious values - authenticity of piety, attention to the spiritual ends and detachment from riches, humbleness and modesty [...] are stressed in the fifth added document, a "brevezica doctrina moral", easily and fluently readable - insofar as it lacks any kind of literary and authoritative references - that, according to Zumárraga, was inspired by Saint Bonaventure's Espejo de disciplina o doctrina de novicios. ${ }^{109}$ The sixth and last moral text consists of a traditional exposition of parental and filial duties. Two short prayers to be said before and after eating come afterwards. The last of Zumárraga's additions to his second rewriting of De la Fuente's catechism is an abridged version of this same "Conclusion exortatoria" found in the previous Doctrina breve muy provechosa (1543-1544). Also, inspired by Erasmus' Paraclesis, it is a reaffirmation of the ideals of simplicity, pragmatism and purity (in an evangelical way) to which Zumárraga adhered even if, for obvious reasons, he had to be cautious proposing such personal theological criteria as a general canon for the formation of new Christians in an enormous and promising diocese as Mexico. ${ }^{110}$

Taking into account all concomitant and apparently contradictory elements in Zumárraga's life and writings, it is difficult to evaluate how sincere his antiLutheran and anti-Erasmian commitment was. As can be seen, the prefatory letters, colophons and additions that he introduced to the compilations of catechetical writings taken from several sources - as is the case for many other religious texts of this period - should be the object of a careful study. Reading between the lines and interpreting these printed materials in the light of Zumárraga's multifaceted life would be imperative in this case.

With regard to his trajectory as bishop and to his role as apostolic inquisitor in Mexico (1536-1543), even the most critical accounts of his actions recognise that, compared with similar figures of this period, he was very indulgent while dealing with those accused of professing Lutheranism. From the five trials that Greenleaf listed and analysed in his classic Zumárraga and the Mexican Inquisition, four concluded with a reprimand, a formal abjuration in the cathedral

108 Zumárraga, Suplemento, fol. mviiiv.

109 This text, one of the most popular books attributed to Bonaventure, had been published on the Iberian Peninsula in Latin before the end of the $15^{\text {th }}$ century (De instructione novitiorum, Montserrat, Johann Luschner, 1499) and was soon translated into Castilian and printed in Seville, Espejo de disciplina, o libro de las cosas pequeñas para los novicios, [Seville], [Estanislao Polono], 1502.

110 Resines, Catecismos Americanos del siglo XVI, vol. 1, 39; Resines, Catecismos Americanos del siglo XVI, vol. 2, 418 . 
of Mexico and a relatively low financial penalty: fifty pesos de oro. The most severe punishment he imposed was the sentence to perpetual banishment from the Indies and seizure of property dictated against Mateo Alemán. It can be seen as a mild sanction given that Alemán had openly and repeatedly criticised confession, excommunication, the images of the saints, papal bulls, indulgences and pontifical authority, appealing instead to the individual reading and interpretation of the Holy Scriptures and supporting the marriage of priests. ${ }^{111}$ The reasons behind the surprising leniency that historians of the Mexican Inquisition such as Greenleaf - almost without ever referring to the catechetical writings of Zumárraga ${ }^{112}$ - did not explain could be linked to a mutual adherence to some of the particular beliefs deemed unacceptable at these same trials. In a turbulent and still not clearly defined - in terms of religious orthodoxy - period, inquisitor and accused could have shared some of the ideas and motivations of their age.

As previously noted, the clear additions that Betanzos and Zumárraga made to Pedro de Córdoba's Caribbean doctrine and the Suplemento of 1546 constitute an explicit refutation of the Protestant attacks on some key dogmas of the Roman Church (purgatory, utility of the works of mercy, virginity of Mary, pontifical primacy, etc.) and on their usual omission in the writings of Erasmus. Nevertheless, Zumárraga seems somehow reluctant when addressing these controversial topics. The corresponding addenda are very schematic and devoid of the characteristic passionate tone of his writing. Even the title of the Suplemento seems in a way tricky, inasmuch as he states that those are "las adiciones que parece que le faltavan", instead of saying clearly and plainly that those were "las adiciones que le faltavan".

On the other hand, the Suplemento is the longest piece added to the 1546 re-edition of De la Fuente's catechism, but not the only one - think of the very Erasmian "Conclusion exortatoria" previously mentioned. Another interesting text is found in the index written by the bishop to introduce the book, a little paragraph that Zumárraga repeats again in the following "Prologo al christiano lector", a rewriting of De la Fuente's prefatory epistles to Bishop García de Loaysa and "Al letor christiano". Instead of correcting or moderating De la Fuente's pastoral minimalism, Zumárraga reinforces the controversial catechetical choice of the Sevillian canon-magistral and adds a further justification to its restrictive doctrinal choice. The pragmatic considerations of De la

\footnotetext{
111 Greenleaf, Zumárraga and the Mexican Inquisition, 1536-1543, 78-82.

112 Greenleaf did not analyse or use any of the doctrines edited by Zumárraga in the 1540s, dealing only with the inquisitorial trials that he found in the Archivo General de la Nación (Mexico).
} 
Fuente are complemented by an appeal to the authority of Paul and the glory of the Ancient Church:

Y aun que aya otras doctrinas que tratan delo mismo: mas no tratan las cosas de nuestra fe con la certinidad y firmeza, que cosa tan firme requiere. Y van confusas y prolixas: contra la doctrina de san Pablo que dezia que mas quería predicar en la iglesia solas cinco palabras que tuviesse bien entendidas: para darlas assi a entender a otros: que diez mil que fuesen no bien entendidas, como el poco manjar corporal bien digesto mas aprovecha, y se encorpora mejor al cuerpo, que lo mucho no bien digerido. ${ }^{113}$

Concluding Remarks. The First American Doctrines, Exceptional Viewpoints of the Emergent Christian Schism

As Alicia Mayer pointed out in her ground-breaking Lutero en el Paraíso, ${ }^{114}$ the shadows of Luther, Calvin, Erasmus and other reformers hang over the American Paradise influencing the missionary strategies of regular and secular churchmen. On the one hand, there was an evident influence of Erasmus and other coeval reformers - some of them European, but especially Spanish reformers such as Constantino de la Fuente - in some of the catechetical materials devised to indoctrinate the Native Americans in this period. On the other hand, even if often only implicitly - not mentioning Luther and other reformers by name - even the more pragmatic and concise doctrine writers seem to have felt compelled to distance themselves from the attacks against purgatory, Mary's virginity and the pontifical potestas.

The case of Zumárraga's doctrines, as the abundant historiography which followed Bataillon's pioneering work attests, figures among the most paradigmatic examples of such an intellectual influence. The re-examination of Zumárraga's brief catechisms in current research on the wide circulation, practical significance and functionality of pragmatic religious literature permits a broadening of knowledge as to the convergence of motivations - practical

113 Zumárraga, Doctrina cristiana: mas cierta y verdadera para gente sin erudicion y letra, fol. air. For the purposes of this contribution, the sentences added by Zumárraga to the original phrasing of De la Fuente have been italicised.

114 Mayer does not address Zumárraga's doctrines, but considers a wide range of other textual (theological treatises, sermons, chronicles, etc.) and iconographic elements. Mayer, Lutero en el Paraíso. 
and theoretical, pragmatic and spiritual - from which the first Mexican doctrines resulted. In the catechetical materials herein reviewed, the ideals of pragmatic simplicity and reformed purification established an uneasy and somewhat fragile alliance. Despite the hesitations and self-censorship that a contemporary reader can easily identify in Zumárraga's texts, the convergence of pragmatism, sobriety and apostolic passéisme tended to foster a catechetical minimalism. Through the outstanding works of Estenssoro, it is known that Zumárraga found emulators in other regions of the Americas. ${ }^{115}$ Even if unable to communicate between themselves, he and his homologue in Lima, Jerónimo de Loayza, operated on similar catechetical choices in the same period and under similar circumstances, ${ }^{116}$ plausibly, under the influence of the same authors of reference in catechetical literary subgenres.

A careful examination of Zumárraga's doctrines also has demonstrated that - in contrast to the conclusions of Mayer,,117 Bataillon, Estenssoro and most of the contemporary scholars examining Christian indoctrination and unorthodoxy in early modern America - clear references to the European debates on the tools of indoctrination for use in America can be found in Mexico even before the conclusion of the Council of Trent. ${ }^{118}$ Moreover, the emergence of an ideological frontier between orthodoxy and heterodoxy in the American missionary context has become visible. As noted, the consciousness of such a frontier and of the dogmatic and disciplinary aspects which were in dispute

115 In his influential Del paganismo a la santidad, Estenssoro called attention to the omissions and silences of the first Peruvian doctrines and suggested that those silences were a kind of singularity of the Peruvian context - Estenssoro, Del paganismo a la santidad, 7576 - and should be understood as a strategy of accommodation to pre-Hispanic beliefs. A detailed comparison between Mexican and Peruvian coeval doctrines shows that such significant omissions have rather to do with the converging pragmatic and spiritual motivations of the missionaries and that silences were very widespread in early American doctrinas.

116 In order to ensure that the natives genuinely learnt some important elements of the Christian faith, Loayza and the Council Fathers of the First Council of Lima (1551-1552) focused on baptism, marriage and penance while identifying the doctrinal contents that should be taught to the Indians. The teaching of other sacraments and of the most complex articles of faith was postponed, Estenssoro, Del paganismo a la santidad, $5^{8-59,} 5^{81}$.

117 "Es interesante notar que en los catecismos indígenas no encontramos referencia alguna al reformador alemán", Mayer, Lutero en el Paraíso, 77. According to her account, one had to wait until the massive importation of Ripalda's catechism (1591) in the 17th century to find a strong and direct opposition to Luther and Lutheranism in New Spain.

118 Like Bataillon, Estenssoro considers it inappropriate to distinguish between orthodox and heterodox catechetical approaches before the 156os, Estenssoro, Del paganismo a la santidad, 74 . 
with Luther or Erasmus was already intense shortly after the onset of the Reformation movement and from the very beginning of the spiritual conquest. The absence of direct references to Luther or to Lutheranism does not imply that, for the missionary agents operating in America, "no tenia caso mostrar a los indios la álgida polémica contra los protestantes que se ventilaba a miles de kilómetros de distancia".119 On the contrary, even if these intra-European debates could be barely understood by the American catechumens, the close supervision of every printed religious book and, especially, of catechetical materials - the means chosen by most of the reformers in order to introduce and disseminate their ideals - obliged the writers of these literary subgenres to be more and more cautious, explicit and detailed in their rejection of nonorthodox ideas. This is the case of Zumárraga, who, as described, resorted to a conscious self-censorship in the rewriting and editing of the catechetical materials he assembled.

As seen in this chapter, two of the doctrines printed in New Spain by order of Zumárraga, adaptations to the Mexican context of the Caribbean doctrine of Pedro de Córdoba and to De la Fuente's Suma, demonstrate that the kind of deficiencies and omissions denounced by the inquisitorial advisors in the late 155 os with regard to De la Fuente's catechism, were clearly already apparent to the bishop and his collaborators by the middle of the 1540s. Despite the evident temptation and need even to be extremely pragmatic, linked with the supposed "weak understanding" of the natives and to the countless difficulties in explaining to them some of the most complicated and illogical mysteries of the Christian faith, Zumárraga did not lose sight of the religious evolution taking place in Spain and Europe and corrected or complemented from the very beginning - more than a decade before the first denunciations of De la Fuente's doctrines - the catechetical materials to be used by the first Mexican apostles.

Zumárraga's minimalistic doctrines and theological interventions in the doctrines of Córdoba and De la Fuente are, beyond doubt, important milestones in the early modern debate about what could be considered expendable parts of the Church's tradition and what, on the other hand, should be considered as essential elements of the Christian faith and inalienable parts of this same Church's heritage. This is an element of crucial interest which invites a re-examination of the secondary and passive-receptive role that previous historiographical perspectives assigned to America and Mexico in the definition of a clear dogmatic frontier between orthodoxy and heterodoxy that took

119 Mayer, Lutero en el Paraíso, 77. 
place in this period. ${ }^{120} \mathrm{~A}$ closer look at the global dimension of the formation of confessional cultures may, therefore, also permit a more precise determination of its proper periodisation.

\section{Bibliography}

\section{Manuscripts}

Archivo General de Indias, Sevilla (AGI), Indiferente, 423, L.19. AGI, México, 1088, L.1.

Archivo General de la Nación, México D.F. (AGN), Inquisición, vol. 43, exp. 4. Archivo Histórico Nacional, Madrid (AHN), Inquisición, Leg. 444, ${ }^{\circ} 5, \mathrm{n}^{\circ} 49$. Biblioteca Nacional de España, Madrid (BNE), R/29333.

\section{Printed Sources}

Acosta, José de, De procuranda indorum salute, Lyon [1588] 1670: Laurent Anisson.

Beltrán de Heredia, Vicente, Los manuscritos del Maestro Fray Francisco de Vitoria O.P.: Estudio critico de introducción a sus Lecturas y Relecciones, Madrid, Valencia 1928. Calvin, Jean, Instruction \& confession de foy, dont on use en Leglise de Geneve, [Genève, Köln 1537]: [Wygand].

Calvin, Jean, Institution de la religion Chrestienne, Genève 1554: Philbert Hamelin.

Catechismus Ex Decreto SS. Concilii Tridentini ad Parochos, Roma 1566: Paolo Manuzio.

Córdoba, Pedro de, Juan de Zumárraga and Domingo de Betanzos, Doctrina cristiana para instruciony información de los indios: por manera de historia, México 1544: Juan Cromberger [Juan Pablos].

Córdoba, Pedro de, Juan de Zumárraga and Domingo de Betanzos, Declaracion y exposicion de la doctrina christiana en lengua española y Mexicana, hecha por los religiosos de la orden de sancto Domingo, México 1548: [Juan Pablos].

De la Fuente, Constantino, Suma de doctrina christiana en que se contiene todo lo principal y necessario que el hombre christiano deve saber y obrar, Sevilla 1543: Juan Cromberger.

120 Pastore, Guerrero and other specialists in the study of the European Reformation point to Mexico as one of the distant and exotic places in which the De la Fuente's Suma was received and reprinted. None of these scholars took into account the careful and systematic adaptations, corrections and additions made by Zumárraga in order to overcome the most important criticisms that De la Fuente's catechism could spark and that, in fact, arose later in the Spanish context. Pastore, Una herejía española, 308-309; Guerrero, Catecismos españoles del siglo XVI, 335-339. 
Erasmus, Enquiridio o manual del cavallero cristiano, trans. Alonso Fernández de Madrid, Alcalá de Henares 1529: [Miguel de Eguía].

Erasmus, Enchiridion o Manual del Cauallero Christiano de D. Erasmo Roterodamo en romance, trans. Alonso Fernández de Madrid, Anvers 1555: Martin Nucio.

Fernández de Oviedo, Gonzalo, Historia general y natural, Madrid 1851-1855.

Gerson, Jean, Confesionario, trans. Juan de Molina, Alcalá de Henares 1519: Arnao Guillén de Brocar.

Gerson, Jean and Juan de Zumárraga, Tripartito del cristianísimo y consolatorio doctor Juan Gerson de doctrina cristiana: a qualquiera muy prouechosa, México 1541: [Juan Pablos].

Libros y libreros en el siglo XVI, ed. Fernández del Castillo, Francisco, México 1914.

Luther, Martin, Der Kleine Catechismus. Fuer die gemeyne Pfarherr vnd Prediger, Marburg 1529: Rhode.

Medina, Miguel Ángel, Doctrina cristiana para instrucción de los Indios. Redactada por Fr. Pedro de Córdoba, O.P. y otros religiosos doctos de la misma orden. Impresa en México, 1544 y 1548, Salamanca 1987.

Molina, Alonso de, Doctrina christiana breve traduzida en lengua Mexicana, México 1546. Paz, Matías de, Del dominio de los Reyes de España sobre los indios, México [1512] 1954. Rickel, Denis van and Juan de Zumárraga, Compendio breve que tracta dela manera de como se han de hazer las processions: compuesto por Dionisio Rickel cartuxano, México 1544: Juan Cromberger [Juan Pablos].

Ripalda, Jerónimo, Doctrina christiana, con una exposición breve, Madrid [1591] 1909.

Vitoria, Francisco de, On the American Indians, in Vitoria. Political Writings, eds. Lawrance, Jeremy and Anthony Pagden, Cambridge 1991, 231-292.

Ximénez, Diego, Enchiridion o Manual de doctrina christiana que tambien puede seruir de confessionario: diuidido en cinco partes [...] hecho y copilado de muchos libros de sana doctrina, Lisboa 1552: German Gallarde.

Zumárraga, Juan de, Doctrina breve muy provechosa de las cosas que pertenecen a la fe catolica y a nuestra cristiandad en estilo llano para comun inteligencia, México [1543-1544]: Juan Cromberger [Juan Pablos].

Zumárraga, Juan de [De la Fuente, Constantino], Doctrina cristiana: en que en suma se contiene todo lo principal y necessario que el cristiano debe saber y obrar, México 1545-1546: Juan Cromberger.

Zumárraga, Juan de [De la Fuente, Constantino], Doctrina cristiana: mas cierta y verdadera para gente sin erudicion y letras: en que se contiene el catecismo o informacion para indios con todo lo principal y necessario que el cristiano deve saber y obrar, México 1546: Juan Cromberger [Juan Pablos].

Zumárraga, Juan de, Regla christiana breve, para ordenar la vida y tiempo del christiano que se quiere salvar y tener su alma dispuesta, para que Jesuchristo more en ella, México 1547: [Juan Pablos]. 
Zumárraga, Juan de?, Manual de adultos, México 1540: Juan Cromberger [Juan Pablos]. Zumárraga, Juan de? Cartilla para la enseñanza de la doctrina cristiana en lengua zotzil, latina y castellana, [México 1547?]: [Juan Pablos].

\section{Literature}

Adeva Martín, Ildefonso, "Estudio preliminar”, in Zumárraga, Juan de (ed.), Regla cristiana breve, Pamplona 1994, i-cxvi.

Adeva Martín, Ildefonso, "Fray Juan de Zumárraga: Regla Cristiana Breve”, in Hispania Sacra 47 (1995), 109-117.

Alejos-Grau, Carmen José, Juan de Zumárraga y su "Regla Cristiana breve" (México 1947): autoría, fuentes y principales tesis teológicas, Pamplona 1992.

Almoina, José, "El erasmismo de Zumárraga”, in Filosofía y letras 15 (1948), 93-117.

Almoina, José, “Introducción”, in Almoina, José (ed.), Juan de Zumárraga. Regla cristiana breve, México 1951.

Aspe Ansa, María Paz, Constantino Ponce de la Fuente. El hombre y su lenguaje, Madrid 1975 .

Borges, Pedro, "La nueva cristiandad indiana", in Borges, Pedro (ed.), Historia de la Iglesia en Hispanoamérica y Filipinas (siglos XV-XIX), vol. 1: Aspectos generales, Madrid 1991, 593-613.

Borges, Pedro, "Métodos de persuasion", in Borges, Pedro (ed.), Historia de la Iglesia en Hispanoamérica y Filipinas (siglos XV-XIX), vol. 1: Aspectos generales, Madrid 1991, 573-591.

Bornstain, Daniel, "Administering the sacraments", in Swanson, Robert (ed.), The Routledge History of Medieval Christianity, 1050-1500, London 2015, 133-146.

Burke, Peter, "Cultures of Translation in Early Modern Europe", in Burke, Peter and Ronnie Po-Chia Hsia (eds.), Cultural translation in Early Modern Europe, Cambridge $2007,7-38$.

Durston, Alan, Pastoral Quechua. The History of Christian Translation in Colonial Peru, 1550-1650, Notre Dame, IN 2007.

Duve, Thomas, "Catequesis y derecho canónico entre el Viejo y el Nuevo Mundo", in Schmidt-Riese, Roland (ed.), Catequesis y Derecho en la América colonial, Frankfurt am Main, Madrid 2010, 131-145.

Duve, Thomas, "European Legal History - Concepts, Methods, Challenges", in Duve, Thomas (ed.), Entanglements in Legal History: Conceptual Approaches, Frankfurt am Main 2014, 29-66.

Estenssoro, Juan Carlos, Del paganismo a la santidad. La incorporación de los indios del Perú al catolicismo. 1532-1750, Lima 2003.

Foljanty, Lena, "Legal Transfers as Processes of Cultural Translation: On the Consequences of a Metaphor", Max Planck Institute for European Legal History Research Paper Series No. 2015-9 (http://ssrn.com/abstract=2682465). 
García Icazbalceta, Joaquín, Don Fray Juan de Zumárraga. Primer obispo y arzobispo de México, 4 vols., México 1947.

García Icazbalceta, Joaquín and Agustín Millares Carlo, Bibliografía mexicana del siglo XVI, México 1954.

García Pinilla, Ignacio Javier, "Más sobre Constantino Ponce de la Fuente y el Parecer de la Vaticana (Ms. Ottob. Lat.789)”, in Cuadernos de investigación histórica 17 (1999), 191-226.

Giesen, Christine, "Audacia y precaución: Constantino Ponce de la Fuente, defensor del protestantismo", in Res Publica 20:2 (2017), 227-241.

Gil, Fernando, Primeras “doctrinas” del Nuevo Mundo. Estudio histórico-teológico de las obras de fray Juan de Zumárraga, Buenos Aires 1993.

Greenleaf, Richard, Zumárraga and the Mexican Inquisition, 1536-1543, Washington, D.C. 1962.

Greenleaf, Richard and Neal Kaveny, Zumárraga and his family: letters to Vizcaya 1536 1548, Washington, D.C. 1979.

Guerrero, José Ramón, Catecismos españoles del siglo XVI. La obra catequética del Dr. Constantino Ponce de la Fuente, Madrid 1969.

Guillermo Durán, Juan, Monumenta catechetica hispanoamericana (siglos XVI-XVIII), 3 vols., Buenos Aires 1984 .

Kamen, Henry, The Spanish Inquisition, London 1965.

Luttikhuizen, Frances, Underground Protestantism in Sixteenth Century Spain, Göttingen, Bristol 2017.

Martín Abad, Julián, La imprenta en Alcalá de Henares: 1502-160o, vol. 3: Catálogo descriptivo (1578-16oo), Madrid 1991.

Mayer, Alicia, Lutero en el Paraíso, México 2008.

Mira Mira, Enrique, Estudio histórico-genético de la "Doctrina breve" (1543-44) de Juan de Zumárraga, Pamplona 1989.

Nesvig, Martin, Ideology and Inquisition. The World of the Censors in Early Mexico, New Haven (CT), London 2009.

Neusner, Josef and Jacques Dupuis (eds.), The Christian Faith in the Doctrinal Documents of the Catholic Church, New York, NY 1982.

Pabel, Hilmar, "Humanism and Early Modern Catholicism: Erasmus of Rotterdam's Ars moriendi", in Comerford, Kathleen and Hilmar Pabel (eds.), Early Modern Catholicism. Essays in Honour of John O'Malley, S.J., Toronto 2001, 26-45.

Pardo, Osvaldo, The Origins of Mexican Catholicism. Nahua Rituals and Christian Sacraments in Sixteenth-Century, Ann Arbor, MI 2006.

Pastore, Stefania, Una herejía española. Conversos, alumbrados e Inquisición (14491559), Madrid 2010.

Resines, Luis, Catecismos Americanos del siglo XVI, 2 vols., Salamanca 1992. 
Ricard, Robert, La conquista espiritual de México. Ensayo sobre el apostolado y los métodos misioneros de las órdenes mendicantes en la Nueva España de 1523-1524 a 1572, México 2002.

Rodríguez, Pedro, El Catecismo romano ante Felipe II y la Inquisición española: los problemas de la introducción en España del Catecismo del Concilio de Trento, Madrid 1998.

Romero Galván, José Rubén, "Review of Sonia Corcuera de Mancera, De pícaros y malqueridos: huellas de su paso por la Inquisición de Zumárraga (1539-1547)”, in Históricas. Boletín de información del Instituto de Investigaciones Históricas 93 (2012), 15-17.

Roulet, Éric, L'évangelisation des Indiens du Mexique. Impact et réalité de la conquête spirituelle (XVIe siècle), Rennes 2008.

Rubial García, Antonio, Notas para el estudio del franciscanismo en Nueva España, 15231550, México 1975 .

Sáenz de Haro, Tomás, "Franciscanismo y espiritualidad. Bibliografía”, in Iglesia Duarte, José Ignacio de la, Francisco Javier García Turza and José Ángel García de Cortázar (eds.), Espiritualidad, órdenes mendicantes y franciscanismo en la Edad Media. VI Semana de Estudios Medievales, Logroño 1996, 301-336.

Sánchez Herrero, José, "Alfabetización y catequesis en España y en América durante el siglo XVI", in Saranyana, Josep Ignasi, Primitivo Tineo, Antón M. Pazos, Miguel Lluch-Baixaulli and María Pilar Ferrer (eds.), Evangelización y teología en América (siglo XVI): XSimposio Internacional de Teología de la Universidad de Navarra, vol. 1, Pamplona 1990, 237-263.

Saranyana, Josep Ignasi, "Métodos de catequización”, in Borges, Pedro (ed.), Historia de la Iglesia en Hispanoamérica y Filipinas (siglos $X V-X I X)$, vol. 1: Aspectos generales, Madrid 1991, 549-571.

Saranyana, Josep Ignasi (ed.), Teología en América Latina, vol. 1: Desde los orígenes a la Guerra de Sucesión (1493-1715), Madrid, Frankfurt am Main 1999.

Soto Guerrero, Antonio, La "Iglesia" en los catecismos mexicanos del siglo XVI editados en México, Roma, 1993.

Tubau, Xabier, "Alfonso de Valdés y la política imperial del canciller Gattinara", in Studia Aurea 4 (2010), 17-43.

Valdeón, Roberto, Translation and the Spanish Empire in the Americas, Amsterdam 2014. Wilkinson, Alexander S. (ed.), Iberian Books: Books Published in Spanish or Portuguese or on the Iberian Peninsula before 1601, Leiden 2010.

Zwartjes, Otto (ed.), Las gramáticas misioneras de tradición hispánica (siglos XVI-XVII), Amsterdam, Atlanta, GA 2000. 